\title{
Degradable and Dissolvable Thin-Film Materials for the Applications of New-Generation Environmental-Friendly Electronic Devices
}

\author{
Xiaoyan Liu ${ }^{1}{ }^{(}$, Mingmin Shi $^{1}$, Yuhao Luo ${ }^{1}$, Lvyang Zhou ${ }^{1}$, Zhi Rong Loh ${ }^{2}$, Zhi Jian Oon ${ }^{2}$, \\ Xiaojuan Lian ${ }^{1} \mathbb{D}$, Xiang Wan ${ }^{1}$, Fred Beng Leng Chong ${ }^{2}$ and Yi Tong ${ }^{1, *}$ \\ 1 College of Electronic and Optical Engineering \& College of Microelectronics, Nanjing University of Posts \\ and Telecommunications, Nanjing 210023, China; 16110720072@fudan.edu.cn (X.L.); \\ b17020906@njupt.edu.cn (M.S.); b17020716@njupt.edu.cn (Y.L.); lvyangzhou@outlook.com (L.Z.); \\ xjlian@njupt.edu.cn (X.L.); wanxiang@njupt.edu.cn (X.W.) \\ 2 School of Engineering, Clean Energy, Temasek Polytechnic, Singapore 529757, Singapore; \\ 1705590F@student.tp.edu.sg (Z.R.L.); 1706408J@student.tp.edu.sg (Z.J.O.); bengleng@tp.edu.sg (F.B.L.C.) \\ * Correspondence: tongyi@njupt.edu.cn; Tel.: +86-139-5100-9852
}

Received: 30 December 2019; Accepted: 10 February 2020; Published: 15 February 2020

check for updates

Featured Application: Thin-film materials with degradability and recyclability for the fabrication of degradable, dissolvable, resorbable, and/or compatible electronic devices, especially transient resistive switching devices for security information storage and neuromorphic computing as well as environmental-friendly applications.

\begin{abstract}
The environmental pollution generated by electronic waste (e-waste), waste-gas, and wastewater restricts the sustainable development of society. Environmental-friendly electronics made of degradable, resorbable, and compatible thin-film materials were utilized and explored, which was beneficial for e-waste dissolution and sustainable development. In this paper, we present a literature review about the development of various degradable and disposable thin-films for electronic applications. The corresponding preparation methods were simply reviewed and one of the most exciting and promising methods was discussed: Printing electronics technology. After a short introduction, detailed applications in the environment sensors and eco-friendly devices based on these degradable and compatible thin-films were mainly reviewed, finalizing with the main conclusions and promising perspectives. Furthermore, the future on these upcoming environmental-friendly electronic devices are proposed and prospected, especially on resistive switching devices, showing great potential applications in artificial intelligence (AI) and the Internet of Thing (IoT). These resistive switching devices combine the functions of storage and computations, which can complement the off-shelf computing based on the von Neumann architecture and advance the development of the AI.
\end{abstract}

Keywords: degradable and disposable materials; metal-oxide thin-film; perovskite thin-film; 2D thin-film; organic thin-film; environmental-friendly; transient electronic devices; resistive-switching devices; printing electronics

\section{Introduction}

With the rapid development of semiconductor technology, electronic and information sciences, and material science, considerable progress and changes have been made in modern electronic devices and daily life. Consequent environmental pollution has also received huge concerns, for instance, waste gas pollution, wastewater pollution, as well as electronic waste (e-waste), and so on. There is an increasing demand for "green electronic" devices because of the environmentally critical problem of 
discarded e-waste on account of the speed up-gradation and the rapid proliferation of electronic devices at an unprecedented pace. These pollutions are hazardous for both the environment and the human race. Great efforts have been made to overcome such problems including gas sensors, wastewater monitoring, air quality control, water purifier, and green electronics [1,2]. Since the concept of resorbable/degradable electronics was introduced in 2009 by Kim et al. [3], it opened up new potentials in the application of electronics. Environmentally friendly electronics based on the resorbable and degradable materials, for instance, degradable substrate polymers, dissolvable conductors, dissoluble semiconductors, decomposable dielectrics, and disintegrable insulators are extensively studied, owing to the superior properties of biocompatibility, biodegradation, and recyclability [2]. Electronic devices with such properties, also known as "transient electronics" [4], can provide capabilities that are complementary to conventional devices and integrated circuits [5]. They are eagerly expected to implement environmental-friendly applications ranging from degradable electronic medical implants, eco-friendly electronics, to environmental sensors, and green disposable consumer devices [6-11]. They are capable of dissolving or disintegrating completely or partially alongside environmentally and biologically benign byproducts in groundwater or biofluids. Compared with their bulk counterparts, many degradable materials prepared in the form of thin films attracted tremendous attention and interest. There are significant differences in dissolution behaviors between bulk and thin-film materials. The degradable thin-film materials are sensitive to crystalline structures, microstructures, porosities, and extrinsic environmental conditions (e.g., light, solution, temperature, and moisture) [2].

As is well-known, the thin-film is a well-established traditional material technology, used for more than half a century, which has made great progress in both electronic devices and the study of integrated electronic circuit engineering. Over the past two decades, rapid advancement has been made in thin-film materials including growth, characterization, and application [12-14]. In recent years, due to the superiority of the electronic, optical, magnetic, and thermal properties of inorganic and organic thin-films, increasing attention and interest has been paid, to these, in the academic and industrial communities [15-21]. These thin-films play a significant role in microelectronics/optoelectronics (e.g., transistors, photodetectors) [22,23]. Thin-films are performing a similar function in the data storage devices industries [24,25]. In 1964, Klasens et al. reported a thin-film transistor (TFT) made of a transparent semiconductor [26], consisting of an insulating layer of aluminum oxide $\left(\mathrm{Al}_{2} \mathrm{O}_{3}\right)$ which was made by anodizing the $\mathrm{Al}$ gate, resulting in a thin layer of the transparent semiconductor evaporating. They proposed a new photographic technique that avoids the elaborate high-precision procedure to prepare a TFT. In 1986, Tsumura et al. fabricated organic TFT using a type of conducting polymer, polythiophene thin-film, which acted as a semiconductor for the first time [27]. The results they obtained suggested that conducting polymers are excellent candidates for forthcoming electronic devices. In the late 20th century, the research of semiconductor materials was still in its early stages, and thin-film techniques were relatively rough. Ever since the beginning of the 21st century, the applications of thin-film have been improving rapidly thanks to the deep research of semiconductor materials and the development of preparation technology of thin-films [28-31]. Particularly, the single-layer graphene was prepared by mechanical exfoliation using scotch tape in 2004 [18], which opened up a new kind of thin-film material, that is, $2 \mathrm{D}$ thin-film materials. Furthermore, with the increasing demand for sustainable development in society, various thin-film materials were extensively studied for environmental-friendly applications such as solar cells [32], energy storage [33,34], sensors (e.g., environmental monitoring) [35-38], catalysis [39], biotechnology (biosensor, flexible, and compatible techniques) as well as emerging transient electronics [3,4,9,21,40-43]. Bettinger et al. fabricated water-stable organic TFTs using biodegradable and biocompatible polymers [21]. These devices consisted of nearly entirely biodegradable materials, hence they are resorbable in an in vitro degradation environment. Rogers et al. put forward transient/degradable electronics based on silicon [3,4], zinc oxide ( $\mathrm{ZnO})$ [42], and polymer thin-films [9]. They studied manufacturing schemes, device fabrication, and integration of such devices and investigated the corresponding electrical, bending, water dissolution, and animal toxicity properties. Boyadjiev et al. presented titanium dioxide $\left(\mathrm{TiO}_{2}\right)$ 
thin-films deposited by atomic layer deposition (ALD) [37]. The obtained results revealed that $\mathrm{TiO}_{2}$ thin-film based gas-sensors are suitable for energy-efficient portable equipment for real-time environmental monitoring of $\mathrm{NO}_{2}$. Martín et al. summarized the latest progress in biocompatibility and biodegradability of graphene-related materials, such as molybdenum disulfide $\left(\mathrm{MoS}_{2}\right)$, hexagonal boron nitride (h-BN), or tungsten disulfide $\left(\mathrm{WS}_{2}\right)$ and discussed the influence of chemical functionalization on the potential control of the biodegradability profile [43]. Yu et al. surveyed materials, processes, and facile manufacturing for bioresorbable electronics in detail [2]. They provided a solution to the growing e-waste problem with applications in temporary electronics such as degradable devices and environmental sensors.

Such research reveals that significant progress has been made in thin-film devices and their applications. However, few reviews investigated resistive-switching devices based on the degradable and compatible thin-film materials. Therefore, our work, apart from summarizing the advancement of thin-film materials and their environmental applications, highlights the eco-friendly resistive-switching devices based on degradable and compatible thin films. In Section 2, traditional preparation methods of thin films are simply introduced and then followed by putting forward the printing technology to prepare thin-film materials. In Section 3, we are devoted to investigating and surveying the research progress in applications for environment-friendly sustainable development from the sensor, catalysis, and/or eco-friendly electronics, etc. based on various thin film mainly including inorganic materials (e.g., metal-oxide, halide perovskite, and 2D) and organic materials in detail. In Section 4, we simply review the research development of eco-friendly devices and emphasize the symbolic progress of memristors. Subsequently, we analyze and envision the possibilities in the implementation of the new-generation environment-friendly electronic devices based on the above-stated thin-films in Section 4 , specifically, resistive switching devices. The last section is a summary and perspective of the review.

\section{Preparation of Thin-Film Materials}

The extensive applications of thin films facilitate the development of film preparation techniques. In general, typical thin-film growth can be divided into both physical and chemical processes $[12,14$, $28,30,44,45]$. The physical process consists of the physical vapor deposition (PVD) process, which involves evaporation from a source and sputtering from a target, and then condensing on the substrate. It includes vacuum evaporation, pulsed laser deposition (PLD), molecular beam epitaxy (MBE), and sputtering. The chemical processes are composed of the chemical vapor deposition (CVD) process and the chemical solution deposition process; a discharge of ions, decomposition of the compounds, and the reaction of gases or liquids with the substrate surface. Due to the limited quantities used on the surface and/or thin-film layers, thin-film materials and devices are available for minimization of toxic materials. In addition, thin-film processing can also improve energy consumption in production, which is highly regarded as an environmentally friendly material technology in the upcoming century.

A large number of methods are employed to prepare inorganic thin-film. For example, the main methods for growing oxide thin-films include oxidation [46], sputtering [47], evaporation [48,49], CVD [47], ALD [50], PLD [51,52], and sol-gel techniques [53,54]. These methods all have their own advantages and disadvantages. For example, PVD is a physical process, which is an eco-friendly technology in contrast to CVD. PVD technology is clean and dry, with no hazardous materials involved, and does not generate chemical waste or water pollution. Thin-film grown by the PVD has high density and few impurities as well as good controllability and repeatability of thickness. While all PVD processes are performed under vacuum. CVD technology is a chemical process, which has a higher deposition rate than PVD. The composition of the film is precisely controllable, and the ratio range is large. For the sol-gel technique, it is a method for producing solid materials from small molecules, which is a cheap and low-temperature technique that allows the fine control of the product's chemical composition. Its mechanical properties and structural stability are enhanced. However, owing to the 
shrinkage of a wet gel upon drying, it often leads to fracture resulting from the generation of large capillary stresses, which makes it difficult for the attainment of large monolithic pieces.

For 2D thin-film, a typical preparation method is a mechanical exfoliation, which was first used to prepare single-layer graphene in 2004 [18]. Since then, CVD [55], PLD [56], MBE [57], and pick-and-lift $\mathrm{vdW}$ techniques [58] were also used for preparing high-quality 2D thin films. Mechanical exfoliation is the main methodology to prepare the single-layer graphene. It is simple in operation and high in sample quality. However, it is low in efficiency and results in high cost, making it unsuitable for mass production in the industry. Therefore, some novel preparation methods were explored and pursued by the researchers, where the environmental-friendly production of graphene attracted tremendous attention and interest under the e-waste pollution and energy shortage. Upadhyay et al. reported a green methodology of synthesis of graphene oxide (GO) via aqueous extract of grapes, which was successfully utilized for the reduction of GO in order to prepare the graphene [59]. This is a promising methodology for the large-scale production owing to the environmentally benign, economical, and facile synthesis approach.

Similarly, there are a multitude of preparation methods for organic thin-films, in which hydroxyl condensation reaction is one of the ways to fabricate organic thin films. As shown in the research [60], a copolymer was fabricated using this method. This copolymer was first synthesized using a hollow rod-like $\mathrm{Mg}(\mathrm{OH})_{2-x} \mathrm{~F}_{x}$ sol with the solvothermal method, and was then fabricated to the organic-inorganic hybrid hydrophobic $\mathrm{Mg}(\mathrm{OH})_{2-x} \mathrm{~F}_{x-}$ MTES copolymer. Furthermore, preparation methods like solvothermal [60,61], photolithography [62], the laser ablation in liquids (LAL) method [63], solvent evaporation [64], interfacial reaction [65], phase inversion [20], spin-coating [66], vapor deposition [67], solution deposition [68], and printing [30] are also widely used.

We can learn that device fabrication usually involves photolithography and etching technology that exposes the material to high temperatures or harsh solvents. In order to circumvent such harsh conditions, printing technology is employed to prepare the disposable environment-friendly electronic devices based on flexible, degradable, and resorbable thin-films. In this case, printing electronics emerge as the times require. It is an electronic science and technology based on traditional printing techniques, combining printing processes and ink chemistry for manufacturing electronic components and devices. Since printing techniques were used for fabricating electronics in the 1950s, different printing processes like screen, inkjet, and laser-induced forward transfer were explored [69-71]. The schematic diagram of printing techniques is shown in Figure 1a [69]. The printing method is one of the "soft" lithographic techniques, which can transfer devices to the degradable, compatible substrates. Figure $1 \mathrm{~b}$ shows the scheme for the general transferring process of devices fabricated on temporary silicon substrates to a final biodegradable substrate [9].

In comparison with the traditional lithography used in microelectronics, printing techniques will lead to the production of flexible, cost-effective, and environmental-friendly electronic products. Therefore, upcoming eco-friendly electronics and artificial intelligence (AI) as an innovative technology are receiving widespread attention, which will drastically change our daily lives. Printed-electronic techniques will make it possible to accelerate this realization. 


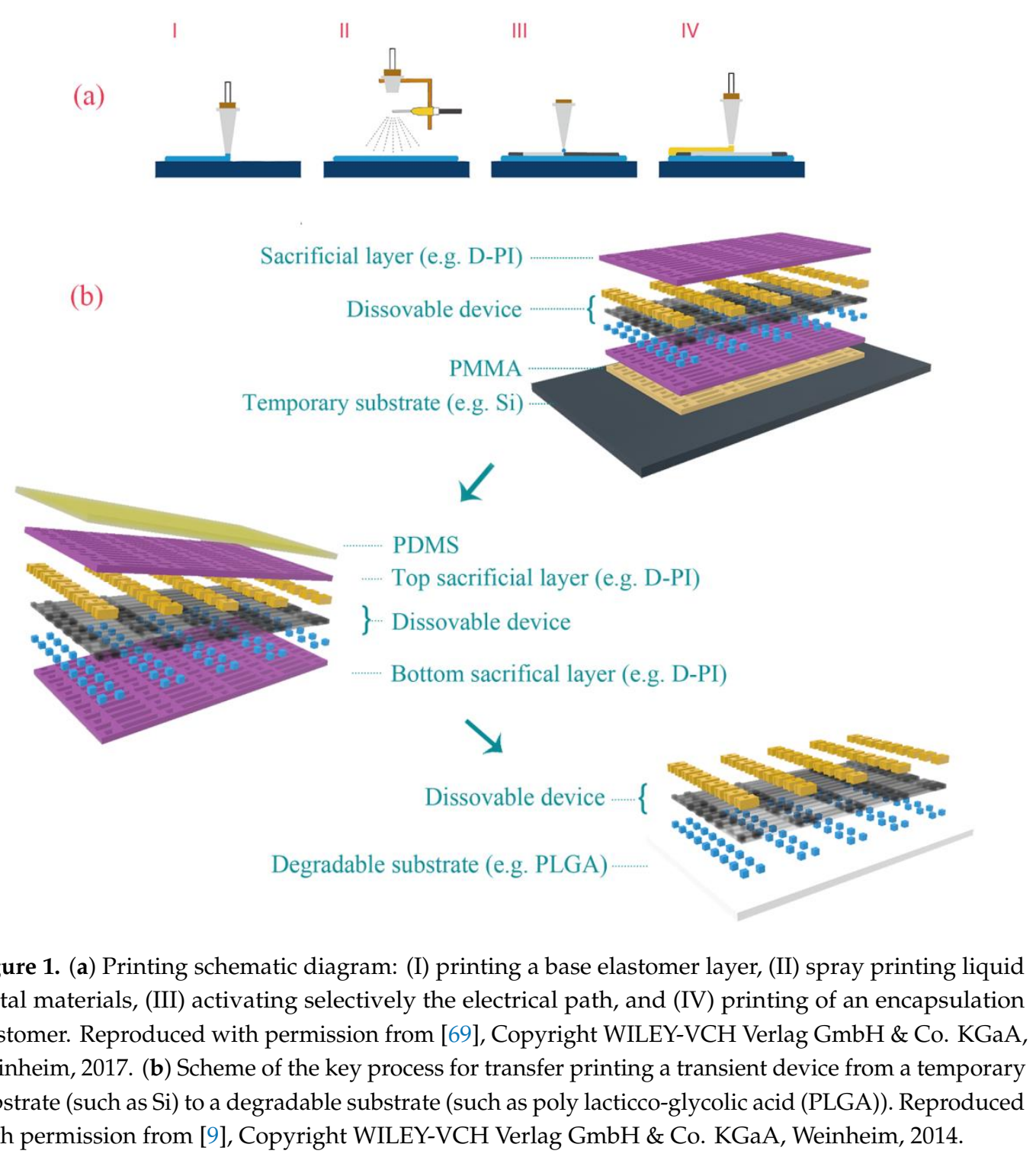

\section{Thin-Film Materials and Their Applications}

\subsection{Inorganic Thin-Film Materials}

Inorganic dissolvable thin-films have been explored including monocrystalline/polycrystalline/amorphous silicon (mono/poly/a-Si), $\mathrm{ZnO}, \mathrm{MgO}$, and indium-gallium-zinc oxide (a-IGZO) as semiconductors [4,42,72-74]; $\mathrm{Mg}, \mathrm{Zn}$, tungsten (W), molybdenum (Mo), and $\mathrm{Fe}$ as conductive materials [5]; and $\mathrm{MgO}, \mathrm{SiO}_{2}$, and silicon nitride $\left(\mathrm{SiN}_{\mathrm{x}}\right)$ for dielectric materials $[4,16,75]$. In water or simulated body fluids (Hanks' solution), the dissolution of them involves hydrolysis to produce corresponding oxides and/or hydroxides which are water-soluble. Therefore, they are selected to use in resorbable, degradable, and compatible applications. Furthermore, great efforts have been devoted to exploring new inorganic materials such as perovskite for environmental applications, especially halide perovskite [33,76-81]. Some researches indicate that halide perovskite materials can also be utilized for various applications in terms of environmental protection, for instance, environmental-friendly sensors, disposable consumer devices, and green electronics $[77,80-82]$. The products we use today are more environmental-friendly and efficient, while the method of obtaining energy is definitely less harmful. In this section, environmental-friendly applications of the various inorganic thin-film materials are reviewed. 


\subsubsection{Metal Oxide Thin-Films}

\section{Binary Metal Oxides}

The development of inorganic materials, especially their oxides, has greatly promoted social progress. Binary oxides with the advantages of simple structure, easy control of material composition, low cost, good stability, and compatible with complementary metal-oxide-semiconductor (CMOS) technology, stays as an important material system in the field of microelectronics. Binary metal oxide thin-films refer to a class of substances in the form of $\mathrm{M}^{\mathrm{I}} \mathrm{O}^{-} \mathrm{M}^{\mathrm{II}} \mathrm{O}$. It has some relatively simple forms like $\mathrm{ZnO}, \mathrm{TiO}_{2}, \mathrm{MgO}, \mathrm{SnO}_{2}$, or $\mathrm{MoO}_{3}$, while having some complex forms like $\mathrm{Fe}_{2} \mathrm{O}_{3}$ or $\mathrm{V}_{2} \mathrm{O}_{5}$. There is not much of a difference between these molecular formulas. But thin films made from these different materials have different functions in the environment. Taking into consideration the promising physical and chemical properties of metal oxide thin-films, they could be applied to gas sensors for waste gas treatment. Some of these can absorb $\mathrm{CO}_{2}$ or $\mathrm{NH}_{3}$, while some others can catalyze $\mathrm{CO}$ into $\mathrm{CO}_{2}$. Other special usage can also be found in the application of metal oxide thin-films, as shown in Figure 2 [36].

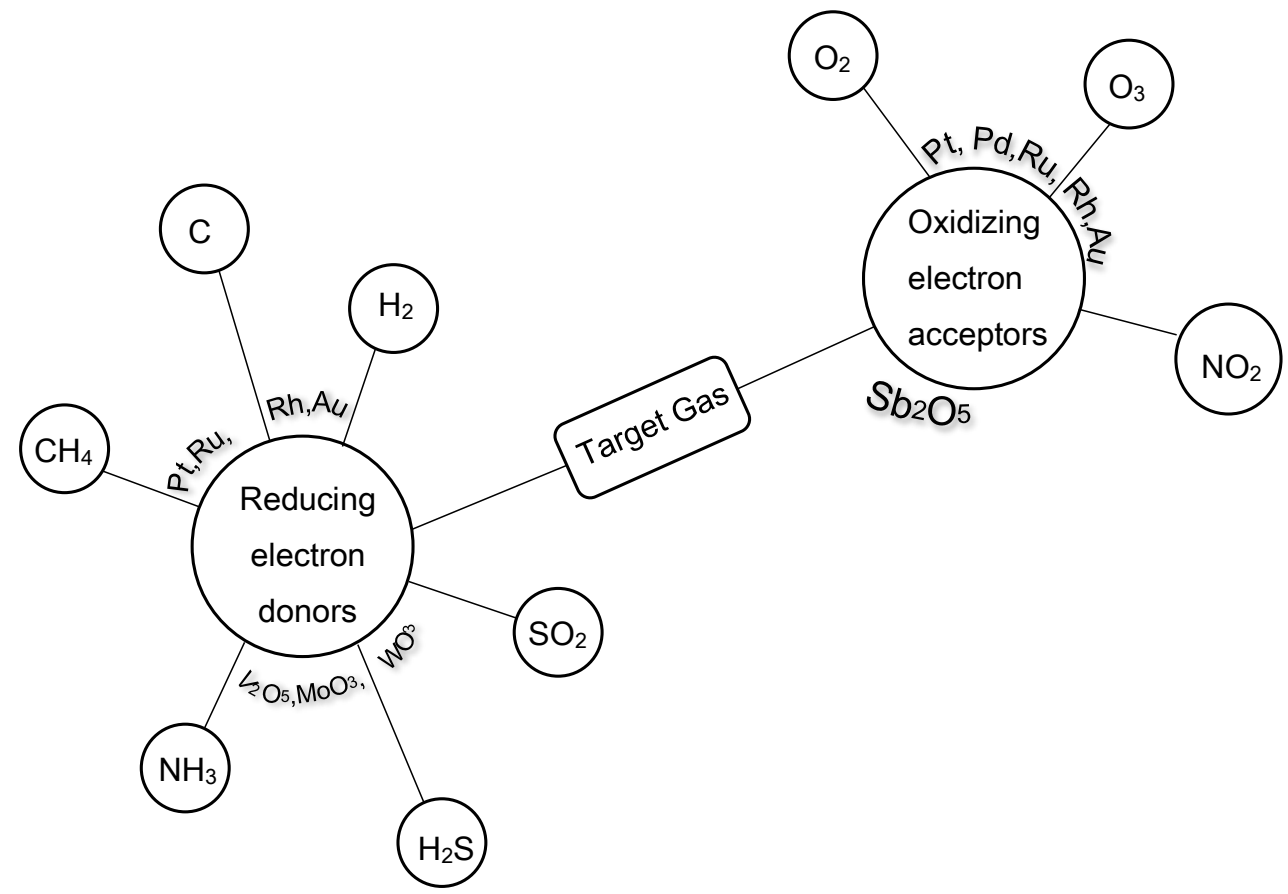

Figure 2. Oxide thin-films with various properties in the application of the waste-gas treatment field. Left part: Reducing gasses' electron donors to make the waste-gas harmless through the ion-exchange membrane; Right part: Oxidizing gases' electron acceptors to make the waste-gas harmless through oxidation catalysis.

Mechanisms of waste gas treatment by the thin film can be divided into two major categories, one is the approach to reduce the gasses' electron donors. In this case, the surface complex is taken place by the solid-gas interaction, so that the chemical nature of the modifier in acid-basic or redox reactions plays a decisive role. When there are some highly efficient platinum metals catalysts ( $\mathrm{Pt}, \mathrm{Pd} \mathrm{Ru}, \mathrm{Rh}$ ) in the reactions, the speed and effect of reflection will be greatly improved. The other approach is acted as oxidizing gases' electron acceptors. In this case, the surface of metal oxide thin-films in the air is covered by chemisorbed oxygen species $\left(\mathrm{O}^{2-}, \mathrm{O}_{2}{ }^{-}, \mathrm{O}^{-}\right)$. At the appropriate temperatures, these thin-films themselves become intermediate catalysts. They make it easier for NO gases in the air to combine with $\mathrm{O}_{2}$ to produce $\mathrm{NO}_{2}$, resulting in easier management. In some specific conditions, thin films could even convert $\mathrm{O}_{2}$ to $\mathrm{O}_{3}$, which could be used in sterilization in the environment. 
Among metal oxide thin-films, $\mathrm{TiO}_{2}$ thin film, a traditional metal oxide material, processes the photocatalytic decontamination ability to deprive of requiring harsh reagents or yielding toxic byproducts, which is also one of the most efficient and environmental-friendly materials for the degradation of contaminants [83-85]. For example, $\mathrm{Li}$ et al. used a $\mathrm{TiO}_{2}$ film (containing gold nanoparticles) as a high-efficient photocatalysis to develop water-driven $\mathrm{Mg}$-based micromotors for photocatalytic decomposition of biological and chemical warfare agents [83]. Compared with $\mathrm{TiO}_{2}$, $\mathrm{ZnO}$ thin film, as a promising metal-oxide semiconducting material, has been widely studied and investigated in many fields including transistors, sensors, energy harvester, catalysis, and resistive switching devices because of biocompatibility, chemical stability, high electron mobility, electrochemical activity, ease of synthesis, and high surface-to-volume ratio [42,86-92]. Hunge et al. successfully synthesized hexagonal $\mathrm{ZnO}$ thin films using the chemical spraying pyrolysis technique, which was used for photo electrocatalytic degradation of terephthalic acid as a model organic pollutant and detecting $\mathrm{CO}_{2}$ gas with high selectivity, good response, and short recovery time periods [92]. The results showed that $\mathrm{ZnO}$ thin film was a great potential candidate for both photocatalytic and $\mathrm{CO}_{2}$ gas sensing multifunctional applications. In 2018, Park et al. proposed that Mg-ZnO Au hybrids can autonomously generate $\mathrm{H}_{2} \mathrm{O}_{2}$ without an instrument for disinfection and organic pollutant degradations [92]. Their system adopted degradable metal (such as $\mathrm{Mg}$ in their work) to activate the photocatalytic reaction of transition metal oxides (such as $\mathrm{ZnO}$ in their work) through a galvanic corrosion process. Other types of oxide thin films are commonly used in the detection of $\mathrm{NH}_{3}$ and $\mathrm{C}_{2} \mathrm{H}_{5} \mathrm{OH}$. The conductivity of thin films varies when the potency of $\mathrm{NH}_{3}$ differs in the environment. Some $\mathrm{NH}_{3}$ detection sensors can be made from this type of thin film. Taking the $\mathrm{SnO}_{2}-\mathrm{MoO}_{3}$ film as an example, its signal intensity varies with corresponding concentration. So, we could conclude that it is the $\mathrm{NH}_{3}$ chemisorption on Lewis acid sites which changes the conductivity [36].

Despite the ability to detect $\mathrm{NH}_{3}$, this type of thin films makes dehydrogenation easier which means it can lead to a higher response to $\mathrm{C}_{2} \mathrm{H}_{5} \mathrm{OH}$ due to a reaction with chemisorbed oxygen $\mathrm{O}_{\mathrm{s}}{ }^{-}$:

$$
\mathrm{C}_{2} \mathrm{H}_{5} \mathrm{OH}+\mathrm{O}_{\mathrm{S}}^{-} \rightarrow \mathrm{CH}_{3} \mathrm{CHO}+\mathrm{H}_{2} \mathrm{O}+\mathrm{e}^{-},
$$

From this reaction, the amount of electrons is increasing, while the conductivity also changes simultaneously. This type of detection is more than just a method of gas detection because it changes the reactant. Therefore, this application is a combination of the two mechanisms above [93-95].

We can conclude that this type of oxidation reaction is usually applied to the treatment of harmful gases in air pollution. When harmful gases in the environment pass through these thin films at a specific temperature, they can be easily converted into gases that are harmless or have a low pollution coefficient. These sensors play a huge role where environmental monitoring is needed. They can provide precise supervisory in real-time under all conditions.

In addition to the above gas detection, binary metal oxides are also considered to be an upcoming new semiconducting material stated in post Moore's law. In the earliest literature, binary oxides have been used in bioresorbable electronics [74] as one of the key materials to fabricate TFTs [96], mechanical energy harvesters [97], supercapacitors [15,98], and non-volatile storage materials [99]. In 2013, Dagdeviren et al. used $\mathrm{ZnO}$ thin-film as the active layer to fabricate water-soluble $\mathrm{ZnO}$ TFTs and energy harvesters/strain gauges [42]. The other components of the $\mathrm{ZnO}$-based devices presented include $\mathrm{Mg}$ for electrodes and interconnection, $\mathrm{MgO}$ for the dielectrics, and films of silk fibroin for the substrate and package. They studied the dissolution properties of the $\mathrm{ZnO}$-based devices in phosphate buffer saline (PBS) and deionized water (DI water). In 2014, Hwang et al. reported biodegradable/transient CMOS on biodegradable polymers [9]. This CMOS consists of $\mathrm{SiO}_{2}$ layer for gate and interlayer dielectrics, $\mathrm{Mg}$ metal-layer for source, drain, gate contacts, and interconnects. More importantly, the poly (methyl methacrylate) (PMMA) and diluted polyimide (D-PI) was used as the sacrificial layer, which is for transferring the CMOS from Si substrate to a biodegradable substrate, such as poly lacticco-glycolic acid (PLGA) in that work. In 2018, Song et al. used MgO thin-film as a resistive-switching layer to fabricate physical transient resistive random access memory (RRAM) with $\mathrm{Mg} / \mathrm{MgO} / \mathrm{W}$ structure [100]. 
The $\mathrm{MgO}$ thin-films were fabricated by the solution process and spin-coating, respectively. After which, they studied the resistive switching performances of $\mathrm{Mg} /$ solution processed $\mathrm{MgO} / \mathrm{W}$ and $\mathrm{Mg} / \mathrm{sputtered}$ $\mathrm{MgO} / \mathrm{W}$ devices in great details. The electronic devices made of the aforementioned materials and structures not only consume lower energy but also have higher computational efficiency.

In the future, another important aspect that restricts social development is energy storage. The method of making a battery with small volume and large energy storage becomes the key to progression. Based on the study of binary oxides, Ni-Co, $\mathrm{Mn}-\mathrm{Fe}$, and $\mathrm{Mn}$-Cu binary transition metal-oxides, it was shown that a combination of their mechanisms can produce supercapacitors $[15,98]$. In addition, the development of transistors is also a primary focus in the field of metal oxide research. In recent years, the continuous improvement of transistor performance is largely accounted for due to the update and progress of conductive medium materials. With the improvement of transistor performance, the electronic products we use today have far lower power consumption than before, making it an outstanding contribution to environmental protection [101,102].

\section{Complex Metal Oxides}

In contrast with binary oxides, complex oxides have higher dielectric constant, which can be utilized as high-K materials. It is found that some complex oxides have ferromagnetic, ferroelectric, and magnetoresistive effects, which allows complex oxides to be implemented into important applications in the field of microelectronics. For example, amorphous a-IGZO [103] and perovskite metal-oxides [104], have been exploited to facilitate the advancement of microelectronics under the bottleneck of Moore's law.

In 2019, Jin et al. presented water-soluble TFTs and circuits based on a-IGZO, which was fabricated with water-soluble materials including $\mathrm{SiN}_{x}, \mathrm{SiO}_{x}$, molybdenum, and polyvinyl alcohol (PVA) [105]. Firstly, the a-IGZO TFTs were fabricated on Si substrate by photolithography, etching, and deposition. Then, the a-IGZO TFTs were transferred onto degradable PVA substrates. They explored the dissolution kinetics for a-IGZO films in deionized water, bovine serum, and phosphate buffer saline solution. The obtained results suggested that the proposed water-soluble a-IGZO TFTs have great application possibilities in biological and environmental resorbable technologies and for temporary biomedical implants. In the same year, Kim et al. proposed an amorphous Al-doped zinc tin oxide (a-AZTO) film instead of the a-IGZO film acting as a resistive-switching layer [106]. Compared with In and Ga elements, $\mathrm{Al}$ and $\mathrm{Sn}$ are relatively safe elements and are common dopants in $\mathrm{ZnO}$ materials, which is contributed to environmental-friendly production. Moreover, the replacement of IGZO with AZTO film can effectively reduce the consumption of in element (a toxic and rare metal), prominently improving environmental safety.

Perovskite materials $\left(\mathrm{ABX}_{3}\right)$ including oxide-perovskite and halide-perovskite are a special kind of inorganic film, whose special characteristic comes from its unique properties. The most remarkable feature is that it can produce a photothermal effect, which means that the conversion of light and electricity in the environment can be realized through these films $[107,108]$. For example, $\mathrm{Pr}_{x} \mathrm{Ca}_{1-x} \mathrm{MnO}_{3}$, $\mathrm{BaTiO}_{3}, \mathrm{SrTiO}_{3}$, Fe-doped $\mathrm{SrTiO}_{3}, \mathrm{DyMn}_{2} \mathrm{O}_{5}$, and $\mathrm{BiFeO}_{3}$ have been broadly investigated for the environmental-friendly sensors and electronic devices [109,110]. Rudraswamy et al. prepared Ag-doped $\mathrm{BaTiO}_{3}-\mathrm{CuO}$ mixed oxide thin film, which was used as a carbon dioxide sensor for environmental pollution and monitoring applications [76]. More complex oxide-perovskite like $\mathrm{La}_{0.6} \mathrm{Sr}_{0.4} \mathrm{Co}_{0.2} \mathrm{Fe}_{0.8} \mathrm{O}_{3}$ perovskite were fabricated by Mirzababaei et al. for a stable anode catalyst for direct methane solid oxide fuel cells [111].

Among complex oxides, there is a family of material known as piezoelectrics (such as perovskite materials) that can interconvert between electrical and mechanical energies. In other words, inputted strain signals can produce an electrical signal for sensors; inverse, inputted electric fields can produce a mechanical deformation. Muralt et al. reviewed the piezoelectric thin films for piezoelectric microelectromechanical systems (MEMS) capable of applying to sensors, actuators, and energy harvester [112]. They investigated the influence of composition, orientation, and microstructure on the 
piezoelectric properties of perovskite thin films (e.g., $\mathrm{PbZr}_{1-x} \mathrm{Ti}_{x} \mathrm{O}_{3}(\mathrm{PZT})$ ) in detail. The materials of this structure can not only achieve photovoltaic thermal effects to obtain energy but also have important applications in bionics. For example, PZT materials combined with $\mathrm{ZnO}$ have a good piezoelectric effect, which can realize high-speed biological vibration on the silicon-based plane. Traditional PZT thin films require complicated fabrication technologies and contain a toxic component (lead $(\mathrm{Pb})$ ), which limits their potential use in flexible and wearable devices as well as in medical implants. Todaro et al. presented a review where new piezoelectric thin films without $\mathrm{Pb}$ were studied (such as piezopolymers, piezoceramic $\mathrm{BaTiO}_{3}$ films, and $\left.(\mathrm{Na}, \mathrm{K}) \mathrm{NbO}_{3}\right)$, which were able for biocompatible, flexible, and compliant piezoelectric energy harvesters for monitoring the environment, an individual's health, wearable, implantable and portable devices, etc. [113].

Finally, traditional perovskite structure thin films can be used in fast oxygen exchange, which means it is somewhat similar to the binary oxide thin films, the $\mathrm{CO}, \mathrm{NO}$, or other gas can obtain oxygen ions when passing through the film, after which, oxidized into harmless gases. The typical structure of this kind is $\mathrm{La}_{0.6} \mathrm{Sr}_{0.4} \mathrm{Co}_{0.2} \mathrm{Fe}_{0.8} \mathrm{O}_{3}$ and $\mathrm{Bi}_{1-x} \mathrm{Sr}_{x} \mathrm{FeO}_{3-\delta}$ [111].

Generally speaking, the excellent properties of perovskite structure polyoxide thin film in the field of light and heat make it possible to be used in the electrodes of photovoltaic power generation or photovoltaic cells, which provides the material foundation for the development of the next generation environmental-friendly energy storage system. At the same time, as an oxide thin film, this kind of film can also embody the characteristics of general oxide films, which have been widely used in environmental sensors such as gas detection or the disposal of waste. More importantly, metal oxide thin-films can be used for dissolvable/transient electronics.

\subsubsection{Halide Perovskite Thin-Films}

Apart from oxide perovskite $\left(\mathrm{ABO}_{3}\right)$, halide perovskite $\left(\mathrm{ABH}_{3}\right)$ materials are of interest in both scientific and technological fields. The most common way to realize the perovskite structure is by using highly efficient and stable semi-transparent $\mathrm{ABH}_{3}$ materials. This structure has a good reaction to light, which produces solar energy (e.g., solar cells) [112]. In addition, it can be used as light-emitting diodes [113], sensors [114,115], and memristors [77].

Under the prevalence of transient/degradable electronics, halide perovskites are exploited to fabricate the aforementioned devices applicable for environmental-friendly degradable sensors, dissolvable consumer devices, and hardware-secured digital systems. In 2017, Zhuang et al. prepared a thiocyanate ion $(\mathrm{SCN})$-doped organometal halide perovskite $\left(\mathrm{CH}_{3} \mathrm{NH}_{3} \mathrm{PbI}_{3}\right)$ thin-film, denoted as $\mathrm{CH}_{3} \mathrm{NH}_{3} \mathrm{PbI}_{3-x}(\mathrm{SCN})_{x}$ thin film [77]. Perovskite-based thin films were used as a sensing material to develop high-performance gas sensors for the detection of acetone or nitrogen dioxide $\left(\mathrm{NO}_{2}\right)$ at room temperature. To date, some efforts have been carried out using perovskite materials as a promising candidate for transient and disposable devices [80,81,116,117]. In 2018, Li et al. for the first time proposed that the transient resistive-switching electronic device with the perovskite $\mathrm{CsPbBr}_{3}$ thin-films acting as resistive-switching functional layer [80]. The investigations on transient characteristics of perovskite-based resistive-switching devices reveal that the $\mathrm{CsPBBr}_{3}$ thin-films and resistive-switching memory device can be dissolved in deionized water within $60 \mathrm{~s}$. Another work used $\mathrm{Cs}_{4} \mathrm{PbBr}_{6}$ thin-films as the switching insulators for fabricating transient perovskite-based resistive-switching memory devices [81]. In that research, dissolution behaviors suggested that $\mathrm{Cs}_{4} \mathrm{PbBr}_{6}$ layers can be rapidly dissolved in a way whereby it fully vanished in DI water after $2 \mathrm{~s}$. It is the reason that the higher sensitivity of $\mathrm{Cs}_{4} \mathrm{PbBr}_{6}$ thin-films with smaller thickness toward DI water than the aforementioned $\mathrm{CsPbBr}_{3}$ thin-films. These researches demonstrate that the halide perovskite-based transient resistive-switching memory devices have great potential for disposable electronics, secure data storage, and artificial synapses. If dissolvable metals were to be selected as electrodes, the fully self-destructive transient electronic device can be fabricated with the entire electronic unit being degradable in DI water. 


\subsubsection{Two-Dimensional (2D) Thin-Film Materials}

In the past decade, owing to the unique electronic, mechanical and optical properties [23,118-122], researchers had an extensive study for 2D materials for various applications. Since the discovery of graphene [18], the field of 2D thin-film materials and research pertaining to the discovery, characterization, and application of novel 2D materials have grown exponentially [123]. The prominent properties of graphene, such as the emergence of a Dirac cone, lead to higher conductivity in the monolayer, and further pushing people to search other promising 2D materials.

Hexagonal boron nitride (h-BN), a structural analog of graphene, was one of the several 2D materials which have been researched next. This special 2D material was predicted to have an obvious bandgap opening and relatively high carrier mobility. Figure 3 shows the structures of three representative 2D materials [124]. The top view and the side view of graphene, boron nitride, and silica (2D silicon dioxide film) are well demonstrated.

(a)

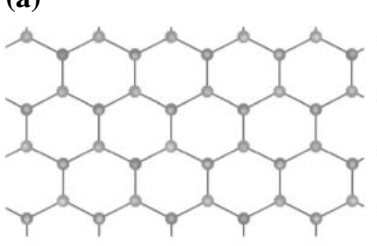

(d) (b)

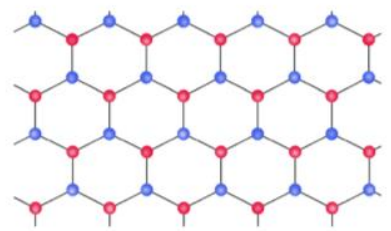

(e)

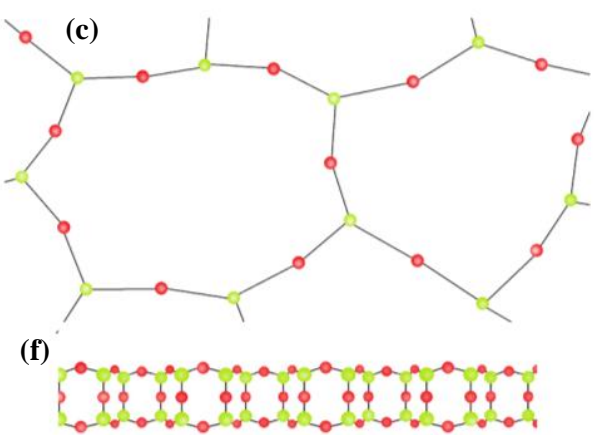

Figure 3. Comparison of graphene, boron nitride monolayer, and silica bilayer. Top view of (a) graphene, (b) boron nitride monolayer, and (c) silica bilayer. Side view of (d) graphene, (e) boron nitride monolayer, and (f) silica bilayer. Reproduced with permission from [124], Copyright American Chemical Society (ACS), 2016. It is worth noting that further permissions related to the material excerpted should be directed to the ACS.

$\mathrm{MoS}^{2}$, with a wide bandgap [125], displays an indirect to direct bandgap transition between monolayer forms and the bulk [126]. While other members of the 2D transition metal dichalcogenide (TMDC) of materials principally have a semiconducting nature, and band gaps are larger than their bulk counterparts.

Recently, transition metal carbides, carbonitrides, and nitrides (referred to as MXenes) are among the latest additions to the 2D world [127-133]. Also, III-V semiconductors [134], II-VI semiconductors [135,136], and many other synthetic varied 2D materials [137-141] have also been predicted.

In this section, we mainly discuss three 2D materials, that is, Graphene, TMDC, and MXene, and summarize their structural characteristics, the status of their development, and some applications.

\section{Graphene}

Graphene, a monolayer carbon hexagonal sheet, is one of the most common materials in both academia and industry. In the past decades, thousands of researchers have studied and reported the fascinating electronic properties of graphene, in both experimental and theoretical aspects. In this section, we introduce graphene and discuss the development history and the discovery of its unique properties. Due to its various properties, this $2 \mathrm{D}$ thin-film can be implemented in many different areas such as graphene-based electronics, energy storage, and composite materials. Especially, environmental-friendly applications are often pursued by individuals.

Since graphene was isolated via mechanical exfoliation in the famous "scotch tape" method for the first time in 2004 [18], Geim and Novoselov received the Nobel Prize in Physics in 2010 for their pioneering research on the preparation of single-layer graphene. Henceforth, graphene in the process 
of being commercialized. There are many potential applications in almost every field from electronics to the environment all thanks to its fascinating electrical and chemical properties.

Most commonly known, solar cells play a key role in solving the energy crisis. Graphene has been proven that it could be utilized in solar cells. Extensive attention has been paid to a variety of solar cells such as crystalline silicon solar cells, amorphous silicon film solar cells, dye-sensitized solar cells, and organic dye solar cells. There are many properties that prompt graphene to the area of a single atomic layer surface which can reach up to $2630 \mathrm{~m}^{2} / \mathrm{g}$, the semiconductor intrinsic mobility can attain $200,000 \mathrm{~cm}^{2} /(\mathrm{V} \cdot \mathrm{s})$, thermal conductivity is about $5000 \mathrm{~W} /(\mathrm{m} \cdot \mathrm{k})$, and the transmittance is $97.7 \%$ with excellent transparency. Thus, graphene is the ideal candidate to substitute previous expensive ITO or fluorine-doped tin oxide (FLO), which is used in solar cells for injection or charge collection.

More importantly, the graphene processes unique biocompatibility and biodegradability, which has stimulated the enormous interest of researchers. Biocompatibility can be said as a type of environmental-friendly property somehow, which means that the materials have the ability to interact with cells, tissues, or a living body without causing harmful effects [43]. Due to its special effects on stem cell lineage specifications, graphene has attracted attention as a platform for cell culture to promote the cardiomyogenic differentiation process of mesenchymal stem cells [142]. Furthermore, further studies show that graphene prepared by the CVD could operate as the favoring growth of neuronal cell substrates with no cytotoxic effects. This property of graphene is not only eco-friendly but also plays a significant role in promoting development in the biomedical field. There is no need to overstate the environmental implications of biodegradability, and it has been proven that some nanostructures like graphene oxide are capable of catalyzing the degradation at the cellular level and in vivo [143-146].

\section{Transition Metal Dichalcogenide (TMDC)}

Due to the layered structure of TMDC similar to graphene, as shown in Figure 4, much research has been done about it. In 2009, Garadkar et al. performed a first principle study in which the $\mathrm{MoS}_{2}$ thin films were acquired in the experiments by means of chemical bath deposition [147].

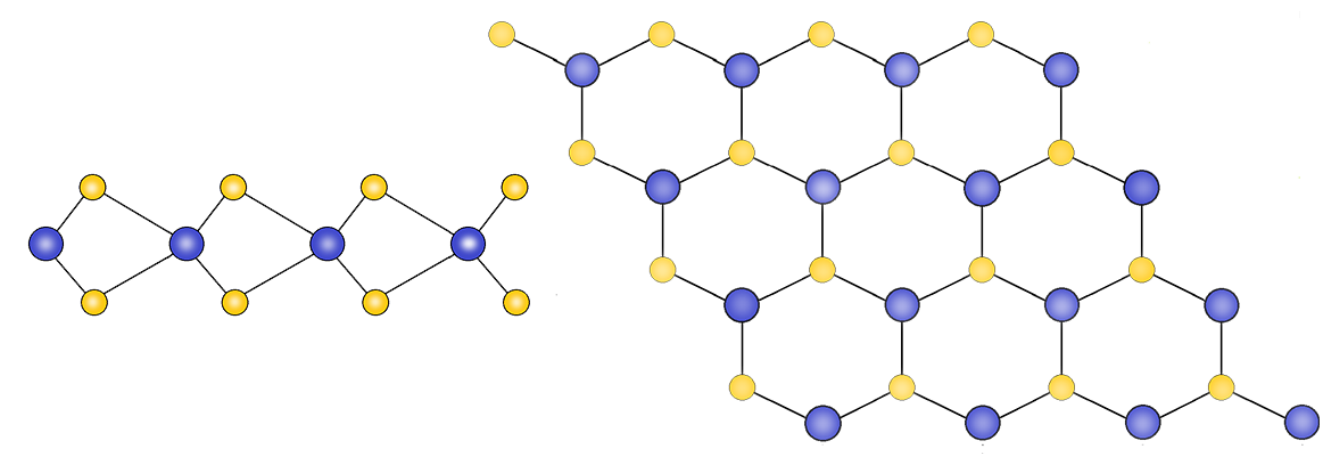

Figure 4. The side and top view of the $\mathrm{MoS}_{2}$ sheet. Reproduced with permission from [148], Copyright Elsevier, 2011.

In further studies, various feasible methods have been used for the deposition of $\mathrm{MoS}_{2}$ thin films, such as the spin coating, microwave synthesis, CVD, metal-organic chemical vapor deposition, sputtering technique, laser evaporation, and pulsed electrodeposition [149-154]. The adjacent layer of this crystal structure may slide due to the weak Van der Waals forces between the layers of S-Mo-S [155]. For investigating the electronic properties of the graphene-like structure TMDC, Ding et al. came to the conclusion that the lattice parameters and stabilities of the $\mathrm{MX}_{2}(\mathrm{M}=\mathrm{Mo}, \mathrm{Nb}, \mathrm{W}, \mathrm{Ta} ; \mathrm{X}=\mathrm{S}, \mathrm{Se}$, $\mathrm{Te})$ sheets depend on the chalcogen atoms [148]. Meanwhile, the electronic properties are primarily determined by the chalcogen. The variation of optical absorbance with wavelength and the variations with inverse temperature have been well demonstrated. Owing to the unique electronic properties of the graphene-like structure TMDC, many applications are already realized, based on it. 
In 2012, Jiménez introduced a model for the surface potential and drain current for monolayer TMD field-effect transistor (FET) [156], considering the 2D density-of-states of the atomic layer thick TMDC and its influence on the quantum capacitance. The work developed an analytical drain current expression that is applicable for both subthreshold and above threshold regions of operation. In 2014, Cao et al. also performed an analytical current-voltage model formulated specifically for 2D TMDC semiconductor-based FETs [157]. In this work, various non-ideal secondary effects have been taken into consideration, such as interface traps, mobility degradation, and inefficient doping. In 2015, Najam et al. considering dielectric interface trap states presented a surface potential-based low-field drain current compact model for 2D TMDC FET [158]. This work, by means of a compact model, successfully extracted the interface trap distribution of $\mathrm{MoS}_{2}$ MOSFETs in which there were a surface potential interface trap charge self-consistent calculation procedure and a drain current expression.

As a graphene-like material, the applications of TMDC are similar to what graphene has to offer. TMDC also has the degradation ability which can be regarded as environmental-friendly. Wang et al. have reported a study that demonstrated that $\mathrm{MoS}_{2}$ is thermodynamically and kinetically unstable to $\mathrm{O}_{2}$, being degraded under ambient conditions in various oxidizing aqueous environments [159].

\section{MXene}

Recently, a new kind of 2D material has been rapidly studied ever since the initial synthesis of $\mathrm{Ti}_{3} \mathrm{C}_{2} \mathrm{~T}_{\mathrm{x}}$ (MXene). MXene is a new family of $2 \mathrm{D}$ graphene-like transitional metal carbides, nitrides, and carbonitrides, whose precursors are MAX phases, as shown in Figure 5 [160]. $\mathrm{Ti}_{3} \mathrm{C}_{2} \mathrm{~T}_{\mathrm{x}}$ was first synthesized successfully by Barsoum et al. via selective etching of the raw $\mathrm{Ti}_{3} \mathrm{AlC}_{2}$ (MAX phases) [127]. Till now, more than 70 species of MAX materials have been developed, which can generally be prepared by the selective etching of certain atomic layers from their corresponding MAX phases using aqueous hydrofluoric acid as the etchant at room temperature [161-164].

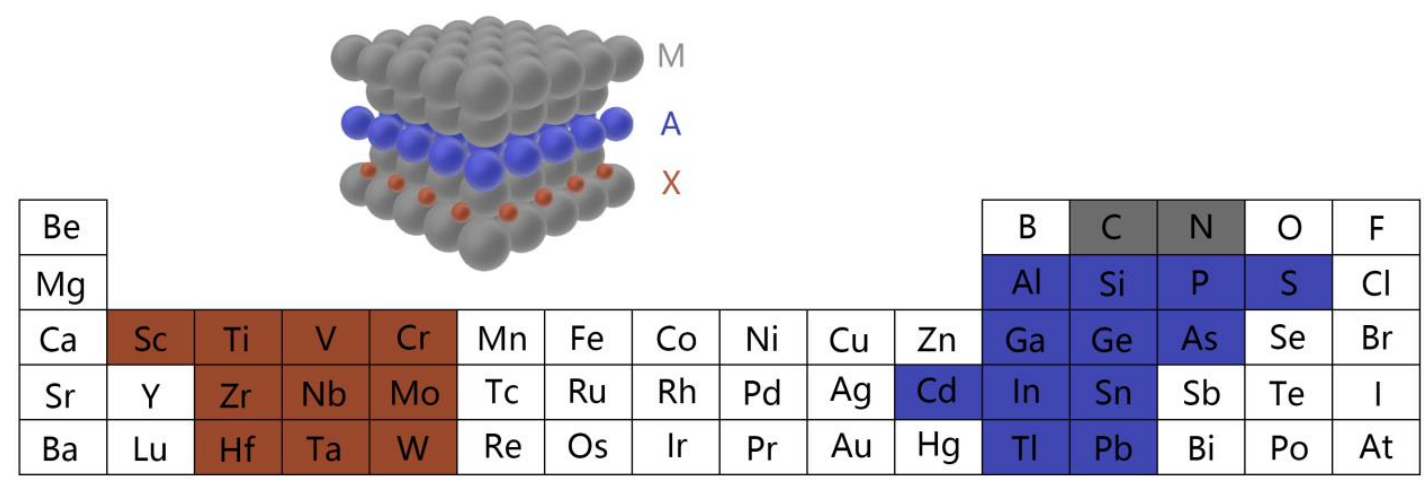

Figure 5. Fragment of the Periodic table. Elements forming MAX phases of the general composition $M_{n+1} A_{n}[n=1,2,3 \ldots ; M$ is a transition d-metal, $A$ is a p-element ( $\mathrm{Si}, \mathrm{Ge}, \mathrm{Al}, \mathrm{S}, \mathrm{Sn}$, etc.), $\mathrm{X}$ is carbon or nitrogen] [160]. Inset: An example of the MAX phases. Reproduced with permission from [160], Copyright Turpion Ltd., 2013.

Various unique properties account for its popularity in the research area. Firstly, Shein et al. have studied that the stability of MXene is excellent via employing first-principle band structure calculations and density functional theory [165]. The lattice energy of MXenes was figured out to be negative values. As is well known, the lattice energy is a crucial parameter to judge the stability of a crystal. The more negative the energy is, the more stable of the crystal. Secondly, MXene possesses fine electronic properties according to the density functional theory. Khazaei et al. reported the research that the dipole moment generated by the $\mathrm{OH}$ functional group is favorable to electron transport, and the conductivity of MXenes is comparable to that of multilayered graphene [166]. Hence, MXene has semiconductor properties which are well worth studying. Thirdly, MXenes have also been found that 
its elastic modulus and bending strength are prominently higher than that of other thin films with the same thickness, such as graphene, which is reported by Murat et al. [167].

What is more, MXene can hold ions and molecules as a layered structure, which has a higher capacity volume than conventional carbon materials per unit. Therefore, lithium-ion batteries (LIBs) can be effectively improved in theory. There are tremendous applications of MXene materials. Here we specifically discuss the application of it being environmental-friendly.

Various studies showed that MXenes have a high hydrogen storage capacity. Hydrogen is widely recognized as a clean energy source [168,169]. It is found to be the most potential alternative to traditional fossil fuel which leads to air pollution and greenhouse gas emission. In 2013, Hu et al. devoted to research the hydrogen storage availability of $\mathrm{Ti}_{2} \mathrm{C}$ [168]. Considering all absorbed hydrogen storage molecules and atoms, the maximum hydrogen storage capacity of $\mathrm{Ti}_{2} \mathrm{C}$ was calculated to be $8.6 \mathrm{wt} \%$ which meets the gravimetric storage capacity requirement set by the U.S. DOE. Seeking for reversible hydrogen storage material remains a great challenge for material scientists and chemists. Hence, MXenes is making a groundbreaking breakthrough in the development of clean energy.

\subsection{Organic Thin-Films}

Organic thin-films possess excellent properties, for instance, mechanical flexibility, low cost, and relative ease of fabrication, which have myriad applications. Over the past two decades, there have always been new applications, which are not easy to realize with traditional electronics with inorganic semiconductors. It has resulted in pushing people to do more research on organic transistors [170,171], photovoltaic cells, energy harvester [61], light-emitting diodes [172], electronic devices [173], sensors [174], and memristors [20]. Compared with inorganic counterparts, organic technologies can address energy and cost inefficiency issues. Moreover, organic thin films play an important role in green electronics, such as degradable small-molecule and polymer thin-film materials $[2,72,175]$. In this review, the distinctive research and the development of thin films made with organic materials for environmental-friendly applications will be introduced in the following sequence.

\subsubsection{Small Molecule and Polymer Thin-Films}

Due to the various types of organic materials, different organic materials vary from one another, resulting in different usage. Nowadays, "green" materials and devices are garnering increasing attention worldwide. Society is well aware of the degrading state on the earth's environment due to pollution caused by waste electronics. The requirements of "green" electronics and energy are becoming stronger. Next, we will expand our review from the preparation methods and applications of these thin films.

Ahmad et al. introduced a new method that allows thin-film composite (TFC) membrane in reverse osmosis (RO) and forward osmosis (FO) to be used for addressing the environmental issues related to oily wastewater [176]. Such economic and environmental-friendly treatment processes for oily wastewater treatment can offer a source of freshwater for reuse and meet the discharge standard, further minimizing serious environmental pollution. Similarly, Khulbe et al. presented TFC and/or TFC polymer hollow fiber (HF) membranes for water treatment, pervaporation dehydration, and gas/vapor separation [177]. In this paper, different types of membranes such as ultrafiltration, reverse osmosis, nanofiltration, and microfiltration are prepared for softening, disinfection, organic removal, and desalination of water and wastewater. In addition, TFC HF membranes prepared via the dip-coating technique were used for sensing and separation of $\mathrm{CO}_{2}$ gas, which can relieve environmental concerns, for instance, climate change, and global warming. RamendraK et al. proposed a poly(3,4-ethylenediox-ythiophene): Poly(styrene sulfonate) (PEDOT: PSS) sensors using photolithography on fully biodegradable and flexible silk, which has proven to have benign cytocompatibility and biodegradability [62]. These sensors can be completely degradable under enzymatic action. Furthermore, they can maintain excellent performances under complex mechanical deformations, showcasing the potential in biosensors. Pang et al. put forward a new material, Alginate [178]. As a natural linear polysaccharide derived from brown 
sea algae using the simple freeze-drying method, the calcium alginate film has porous structures which will be beneficial for triboelectric power generation. This calcium alginate film originates from the ocean initially and can be finally degraded in the ocean, which is thought to be an environmental-friendly ecosystem. Zhang et al. raised a degradable and flexible nanocomposite film fabricated with poly lactic acid (PLA), nano ZIF-8@GO, and degradable flame-retardant resorcinol diphenyl phosphate (RDP) [179]. These environmentally friendly biodegradable polymers are ideal candidates for solving today's electronic waste pollution.

Therefore, further works develop the degradable and transient devices for "green" microelectronic applications. In 2016, Liu et al. fabricated a biodegradable synaptic transistor on graphene-coated PET substrate gated by a chitosan-based biopolymer electrolyte film [180]. Chitosan is a naturally abundant, non-toxic, and degradable polymer [181]. The proposed transistor could be dissolved in deionized water, indicating the potential biodegradable and "green" synaptic transistor applications. In 2018, a water degradable biopolymer-based indium-tin-oxide (ITO) synaptic transistor was proposed by Li et al., where starch-based biopolymer electrolyte was used as the gate dielectric [178]. The proposed biopolymer-based oxide synaptic transistor exhibits high stabilities in synaptic response. After mimicking both short-term and long-term synaptic plasticity, it shows the potential applications in "green" neuromorphic platforms. In 2019, our group used natural chicken album thin-film prepared by spin coating as the gate dielectric to fabricated electric-double-layer (EDL) TFTs [182]. The albumen-gated TFTs exhibit an ultralow operation voltage, high field-effect mobility, a low subthreshold swing, a large on-off ratio, and good reproducibility in response to the repeatedly pulsed gate voltage. Such EDL-TFTs with albumen electrolyte as the gate dielectric will be useful for the biodegradable and low-energy portable electronic products.

\subsubsection{Inorganic-Organic Hybrid Thin-Films}

Inorganic-organic composite systems are another significant research filed of the microelectronics. Such as nanostructure materials (e.g., metal and/or oxide nanoparticles) embedded in organic thin-films, perovskite thin-films with organic functional groups (e.g., $\mathrm{CH}_{3} \mathrm{CH}_{3} \mathrm{BrI}_{3}$ ), and so on.

In the industry, nanostructured thin films are manufactured in various ways. Solution-processed [174,183], green electrospinning technique [184], embedded with nanoparticles, shaped with nanostructuring techniques, or hybridized with other systems or functionalized with bio nanotechnological methods are used. Different ways can result in different properties [178]. These properties include photocatalytic, antibacterial, antifouling, and abrasion-resistant. With the development of nanotechnology, the production of various forms of nanostructured materials is added to organic materials, such as nano-layers, nanoparticles, and nanowires. It is reported that the environmental-friendly $\mathrm{N}$-doped $\mathrm{TiO}_{2}\left(\mathrm{~N}-\mathrm{TiO}_{2}\right)$ nanorods in regenerated cellulose composite thin films were designed as a green portable photocatalyst by utilizing recycled newspaper as a sustainable cellulose resource [185]. The fabrication process is environmental-friendly and shows great potential in the field of water and wastewater treatment applications. Catalytic thin-films offer great potential for green technology applications in order to save energy, combat pollution, and reduce global warming $[185,186]$. In 2016, an article reported a biodegradable triboelectric nanogenerator (BD-TENG) capable of using in vivo biomechanical energy harvesting [187]. This BD-TENG is posed of the biodegradable polymer as the frictional layer and resorbable metals ( $\mathrm{Mg}$ film) as the electrode layers, which can be degraded and resorbed in an animal body. The output performance in vivo, biocompatibility, and tunable degradation property of the BD-TENG were systematically analyzed. Excellent experimental results demonstrate the potential as a power for transient medical devices, which can be used to supply in the field of biomedical science, especially in vivo sensors and therapeutic devices. Biomedical science has developed rapidly and achieved great results in recent years. The prepared nanofiber films, owing to the green electrospinning technique and the appropriate content, get higher points in the biocompatibility and biodegradation test [184]. In addition, the results of the 
cytotoxicity reveal the possibility of coexistence with human dermal fibroblast cells. In conclusion, the nanofiber films show the potential to be applied in skin tissue engineering scaffold applications.

Such degradable, resorbable and/or compatible hybrid inorganic-organic thin films are able to implement transient electronic devices. In 2017, Shi et al. fabricated the dissolvable and recyclable random laser (DRRL) based on the mixture of semiconductor NPs with a water-soluble polymer [188]. $\mathrm{ZnO}$ NPs (gain media) and $\mathrm{TiO}_{2} \mathrm{NPs}$ (scattering media) are embedded into PVA. The dissolvable behaviors of the DRRL were studied in water, and the recycling capability was also demonstrated. The NPs-embedded in polymer-based lasers can be dissolved completely in DI water and can be reused for several times. Fang et al. proposed a degradable poly (vinyl alcohol)-based (PVA-based) composite thin-films doped with $\mathrm{TiO}_{2} \mathrm{NPs}\left(\mathrm{PVA} / \mathrm{TiO}_{2}\right)$ [189]. Through controlling the $\mathrm{TiO}_{2}$ nanoparticle addition, the dielectric properties and dissolution rate of the composite film can be tuned. The $\mathrm{PVA} / \mathrm{TiO}_{2}$ water-solubility composite was also used to further design and fabricate patch antennas, which could be physically degraded in pure water. In 2019, foldable and biodegradable energy-storage devices based on copy papers were developed by Park et al. [190]. An electric double-layer capacitor was made on copy papers while using pencil-drawn electrodes that are made with silver nanoparticles (AgNPs) and reduced graphene oxide (rGO). Li-doped chitosan/starch as an electrolyte and AgNPs/rGO based pencil material as electrodes consist of energy-storage devices. Chitosan and starch are naturally biodegradable polymers. Therefore, they are environmentally friendly and will not produce harmful by-products.

\section{Environment-Friendly Electronic Devices}

In the 21st century, environmental concerns and end-of-life disposal problems from the e-waste are grand challenges all around the world that demand eco-friendly electronics for mitigation of these issues. From Section 3, we can observe that considerable efforts have been made to study transient electronic devices and systems focusing on disposable transistors, diodes, sensors, energy harvesters, CMOS, logic circuits, memristors, and so forth [9,42,105,191-193]. However, there are few reviews surveying and investigating the degradable and/or compatible resistive-switching device. The new-generation environmental-friendly memristors based on degradable, resorbable, compatible, and/or recyclable thin-film materials are a prominent and promising area of research, which will result in advancing the development of the AI and progress a step further in practical applications. In subsection, we give a simple overview and promising perspectives about transient resistive-switching devices.

Memristor, as the fourth fundamental electrical passive element, was first postulated by Leon Chua in 1971 when he studied the relationships among charge, current, voltage, magnetic flux [194]. Memristors are featured with exclusive resistive switching characteristics enabling for green data storage and security brain-like computing, which attracts immense attention and interest. In the 1960s, Hickmott et al. from General Electric Research (GER) laboratory first reported that the $\mathrm{Al} / \mathrm{Al}_{2} \mathrm{O}_{3} / \mathrm{Al}$ structure had the resistive-switching characteristics [195]. After which, more metal oxide materials, such as $\mathrm{NiO}, \mathrm{TiO}_{2}, \mathrm{ZnO}, \mathrm{MgO}$, and $\mathrm{WO}_{x}$ were found to possess a resistive switching effect [196-200]. Fast forward to the 1990s, Asamitsu et al. proved that the $\operatorname{Pr}_{1-x} \mathrm{Ca}_{x} \mathrm{MnO}_{3}$ materials with a perovskite structure exhibit large changes in electronic resistance [201]. Since then, the related research of the resistive switching devices mainly focused on complex metal oxides such as manganite and titanate in perovskite structures. However, the application prospect of complex thin-film materials with perovskite structure in memory is unclear due to the complexity of the processing technology. Difficulty in the control of composition and incompatible with CMOS technology was observed. Until 2008, Strukov et al. from Hewlett Packard Laboratories (HP Labs) reported an article entitled "The missing memristor found" in Nature [202]. They first studied the physical behavior of the resistive-switching devices. Henceforth, more and more thin-film materials and devices with resistive switching behaviors were exploited and introduced as memristors. To this date, a large number of thin-film materials have been implemented into applications on resistive-switching devices. 
Based on the aforementioned Section 3, we review and envision the transient/dissolvable memristors based on the degradable, resorbable, disposable, and/or compatible inorganic, organic, and 2D thin-films.

Dang et al. reported a fully physical transient/biodegradable bio-inspired artificial synapse based on a $\mathrm{W} / \mathrm{MgO} / \mathrm{ZnO} / \mathrm{Mo}$ memristor on the silk protein substrate for the first time [173]. $\mathrm{W}$ and Mo were utilized as electrodes which are biocompatible and biodegradable. $\mathrm{MgO}$ and $\mathrm{ZnO}$ were employed as resistive switching layers being able to dissolvable and biodegradable. The $\mathrm{MgO} / \mathrm{ZnO}$ double dielectric layers were designed and fabricated to obtain stable analog resistive switching behaviors.

Zhong et al. proposed the novel transient $\mathrm{Mg} / \mathrm{MgO} / \mathrm{W}$ RRAM with controllable degradation by introducing a bilayer of a light-responsive hydrogel and oxide thin-film [203]. Under the gel-to-sol transition process with UV light present, the fully soluble RRAM with the controllability of triggering degradation was successfully achieved.

In 2016, Zhang et al. presented the biodegradable RRAM consisting of three thin-films, that is, magnesium difluoride $\left(\mathrm{MgF}_{2}\right)$ used as the switching layer, $\mathrm{Mg}$ and Fe acted as electrodes [204]. The switching layer $\left(\mathrm{MgF}_{2}\right)$ is biodegradable. Such biodegradable RRAM devices were fabricated on a polyethylene terephthalate (PET) substrate, which also can be dissolved when they were placed in DI water.

Liu et al. developed a physical transient memristor with the $\mathrm{MgO}$ thin film as a resistive dielectric layer and the $\mathrm{Ni}$ metal layers as electrodes, which was fabricated on $\mathrm{aiO}_{2} / \mathrm{Si}$ substrate [8]. The $\mathrm{Ni} / \mathrm{MgO} / \mathrm{Ni}$ structure can be exfoliated from the $\mathrm{SiO}_{2} / \mathrm{Si}$ substrate, and then submerged into the DI water. Due to the lack of a supporting substrate, the $\mathrm{Ni}$ and $\mathrm{MgO}$ thin-films dissolve in water.

$\mathrm{Li}$ et al. for the first time proposed the all-inorganic transient perovskite $\mathrm{CsPbBr}_{3}$ nonvolatile resistive switching memory device with $\mathrm{Ag} / \mathrm{CsPbBr}_{3} / \mathrm{PEDOT}$ : PSS/ITO/PET structure [80]. The perovskite $\mathrm{CsPbr}_{3}$ thin-film was used as the active layer. The PEDOT: PSS layer was deposited on the ITO electrode to enhance the adhesion of $\mathrm{CsPbBr}_{3}$ thin films, and the ITO layer was used as the bottom electrode. They verified that the resistive switching mechanism is ascribed to the formation and dissipation of $\mathrm{Ag}$ conducting filament at the $\mathrm{CsPbBr}_{3}$ layer.

Organic thin-film materials such as egg albumen (or egg white) and silk are natural polymer materials that can be biodegradable, bioabsorbable, and environmental-friendly. So, the use of the organic thin-film as the active resistive switching layer is promising in transient memristor fabrication.

Hosseini et al. employed natural chitosan thin-film as the solid polymer electrolyte layer and the dissolvable $\mathrm{Mg}$ as electrodes to fabricate fully biodegradable resistive switching memory on the plastic/rice paper substrate [205]. They investigated the dissolution evolution of the $\mathrm{Mg} / \mathrm{Au}$-doped chitosan/Mg resistive-switching devices in the water in detail, as well as resistive switching performances and retention capability. The obtained results implied that the fabricated chitosan-based organic memristor with Mg electrodes is highly promising for biodegradable and environmentally benign memory applications.

Metal nanoparticles/organic thin-film hybrid materials acted as organic resistive-switching functional materials are another hot topic of organic-inorganic resistive-switching devices. In this case, metal thin-films/nanoparticles or metal-doping nanocrystals are embedded in organic RS functional materials.

Wu et al. reported a degradable resistive-switching nonvolatile memory based on Al/Au NPs: lignin/Al sandwiched structure, where gold nanoparticles embedded alkali lignin (Au NPs: lignin) was used as the biodegradable active layer fabricated by solution-process method, and the PLA thin-film was also used as a degradable skin-inspired substrate [206]. Au NPs in the active layer are responsible for the resistive-switching mechanism. Such memory devices can be degraded in a proteinase K aqueous solution.

Other transient/degradable resistive-switching devices have also been developed using degradable, resorbable, and/or biocompatible thin-film materials, which are shown in Table 1. 
Table 1. Overview of dissolvable resistive-switching devices.

\begin{tabular}{|c|c|c|c|}
\hline Group & Transient Resistive-Switching Structure & Trigger & Application \\
\hline Dang B. [173] & $\mathrm{W} / \mathrm{MgO} / \mathrm{ZnO} / \mathrm{Mo}$ & $\mathrm{PBS}^{\mathrm{a}}$ or DI water ${ }^{\mathrm{b}}$ & $\begin{array}{l}\text { Bio-inspired artificial } \\
\text { synapse }\end{array}$ \\
\hline Zhong S. [203] & $\mathrm{Mg} / \mathrm{MgO} / \mathrm{W}$ & $\begin{array}{l}\text { DI water or PBS under } \\
\text { ultraviolet light }\end{array}$ & RRAM $^{c}$ \\
\hline Song F. [207] & $\begin{array}{l}\mathrm{Mg} / \mathrm{ZnO} / \mathrm{W} \text { and } \mathrm{Mg} / \mathrm{ZnO} / \mathrm{Mg} \text { with silk } \\
\text { fibroin substrates }\end{array}$ & DI water or PBS & Memory \\
\hline Liu D. [208] & $\begin{array}{c}\mathrm{Cu} / \mathrm{a}-\mathrm{Si}^{\mathrm{d}} / \mathrm{W} \text { on a poly(vinyl alcohol) } \\
\text { substrate }\end{array}$ & Water & Memristor \\
\hline Song F. [100] & $\mathrm{Mg} / \mathrm{MgO} / \mathrm{W}$ & Water & RRAM \\
\hline Zhong S. [209] & $\mathrm{W} / \mathrm{Cu} / \mathrm{SiO}_{2} / \mathrm{W}$ & Water or PBS & Resistive memory \\
\hline Zhang Z. [204] & $\mathrm{Fe} / \mathrm{MgF}_{2} / \mathrm{Mg}$ & DI water & RRAM \\
\hline Sun J. [210] & $\mathrm{W} / \mathrm{Ag} / \mathrm{MgO} / \mathrm{Ag} / \mathrm{W}$ & DI water & Memristive Synapse \\
\hline Liu D. [8] & $\mathrm{Ni} / \mathrm{MgO} / \mathrm{Ni}$ on $\mathrm{SiO}_{2} / \mathrm{Si}$ substrate & $\begin{array}{l}\text { DI water after exfoliating } \\
\text { the substrate }\end{array}$ & $\begin{array}{l}\text { Nonvolatile bipolar } \\
\text { memory }\end{array}$ \\
\hline Liu R. [180] & InZnO/Chitosan/ITO/Graphene/PET & DI water & synaptic transistor \\
\hline Li Q. [80] & $\mathrm{Ag} / \mathrm{CsPbBr}_{3} / \mathrm{PEDOT}: \mathrm{PSS} / \mathrm{ITO}$ & DI water & Nonvolatile memory \\
\hline Hosseini, N.R. [205] & $\begin{array}{c}\mathrm{Mg} / \mathrm{Ag} \text {-doped chitosan/Mg on plastic } \\
\text { substrate }\end{array}$ & Water & Nonvolatile memory \\
\hline Wu W. [206] & $\mathrm{Al} / \mathrm{Au}$ NPs: alkali lignin $\mathrm{e} / \mathrm{Al}$ & $\begin{array}{l}\text { Proteinase } \mathrm{K} \text { aqueous } \\
\text { solution }\end{array}$ & Nonvolatile memory \\
\hline Ji X. [211] & $\mathrm{W} /$ silk fibroin/Mg & PBS & Memory \\
\hline Yan X. [212] & W/egg albumen/ITO/PET ${ }^{\mathrm{f}}$ & Water & Artificial synaptic device \\
\hline Wang H. [213] & $\mathrm{Au} / \mathrm{Mg} /$ fibroin/Mg & DI water or PBS & $\begin{array}{l}\text { resistive-switching } \\
\text { memory }\end{array}$ \\
\hline
\end{tabular}

The above-investigated reviews suggest that the degradable, resorbable, dissolvable, and/or compatible thin films including metal oxide thin-film materials (e.g., $\mathrm{ZnO}, \mathrm{MgO}, \mathrm{SiO}_{2}$ ), and organic materials (e.g., protein, silk, cellulose) can be used effectively as memristive dielectric functional materials for eco-friendly resistive-switching devices. For electrode materials of the resistive-switching devices, metal thin-film such as $\mathrm{Pt}, \mathrm{Au}, \mathrm{Mg}, \mathrm{Mo}, \mathrm{Al}, \mathrm{W}, \mathrm{Zn}$, and/or Fe. were used to prepare dissolvable top/down electrodes. However, as observed, the degradable and/or compatible resistive-switching devices based on the 2D thin-films are hardly reported. Therefore, there is still a need to make considerable efforts in the development of transient resistive-switching devices. According to Section 3.1.3, for some 2D thin-films (e.g., graphene, $\mathrm{MoS}_{2}, \mathrm{hBN}$, black phosphorus), they have the degradation possibilities under the presence of the catalysis. Therefore, the thin-film materials described in Section 3 lay the substantial foundations for broad classes of transient resistive-switching devices. The dissolvable metals (e.g., $\mathrm{Mg}, \mathrm{W}$, etc.) would be used as electrodes or interconnections. The degradable $2 \mathrm{D}$ thin-films can be used as resistive-switching functional layers. $\mathrm{Si} / \mathrm{SiO}_{2}$ and organic film (e.g., silk or polylactic acid) acted as substrates/packaging materials on which would be fabricated or transferred by printing technologies. Such thin film-based green electronics are known as transient electronics or degradable electronics, which may help relieve the environmental issues of discarding e-waste. The alone usage of degradable materials, or heterogeneous integration, opens up additional application possibilities for transient technologies ranging from biomedicine to environmental monitoring and consumer electronics. Particularly, resistive-switching devices are an emerging nonlinear memory with simple structures, low power consumption, and high operation speed, which has both memory and logic computing functions. With the development of intelligent terminals, the demand for degradable and wearable electronics is increasing, and the field of the AI also needs to develop towards the direction of flexibility, wearability, and degradability. Therefore, the development of such flexible and resorbable resistive-switching devices for the purpose of security information storage and brain-inspired computing will open up a new application direction in the field of AI. 


\section{Conclusions and Future Perspectives}

Thin film technology has been utilized for more than half a century and is still being evolving on a daily basis due to its key role in the 21st development of new thin-film materials and novel thin-film devices. Specifically, it is used for facilitating the advancement of next-generation environmental-friendly devices, which are capable of environment sensing, health monitoring, "green" electronics, and so on. The literature review provides an overview of environmental applications based on various thin-films, mainly including inorganic materials (e.g., metal-oxide, halide perovskite, 2D) and organic materials. Before that, preparation methods of thin films were introduced simply, and then printing techniques were proposed for producing flexible, cost-effective, and environmental-friendly electronic products. Then, inorganic thin films including metal-oxide, PZT, halide perovskite, 2D thin-films, as extensively used thin-film materials, in applications of waste-gas/water sensing, energy, storage, etc. were reviewed in greater details. In light of the degradability and resorbability of partial inorganic thin films, they can be employed to fabricate the transient/degradable electronics for alleviating e-waste pollution threats. 2D material is one of the most popular low-dimension materials, which are of significance in academics and industries. Consequently, the properties and environmental applications of 2D thin films, such as degradability and compatibility as well as sensing of waste-gas/water pollution and storage of clean energy. To truly realize the complete transient/degradable electronics, except for inorganic thin-film materials, organic thin-film materials are desirable thanks to the unique advantages of recyclable degradation, resorbability, flexibility, and compatibility. Therefore, the small molecular and polymer thin-films as well as inorganic-organic thin-films applied for environmental protection and degradable devices are reviewed. After which, this paper highlights the perspective of the transient resistive-switching devices (such as transient RRAM), which provides abilities for the embedded system or Internet of Things (IoT) edge computing side, such as autonomous driving, smart sensors, and wearable devices. Furthermore, the memristor-based artificial degradable and/or compatible synapse is highly desirable for security neuromorphic computing and bio-integrated systems, which is a promising candidate for the new generation memory and computing systems in AI applications.

Author Contributions: Conceptualization, Y.T., and X.L. (Xiaoyan Liu); writing-original draft preparation, X.L. (Xiaoyan Liu), M.S., Y.L., and L.Z.; writing-review and editing, X.W., X.L. (Xiaoyan Liu), F.B.L.C., and Y.T.; visualization, Z.R.L., and Z.J.O.; supervision, Y.T.; funding acquisition, Y.T., X.L. (Xiaojuan Lian), and X.W. All the authors contributed to the work. All authors have read and agreed to the published version of the manuscript.

Funding: This work was supported in part by the National Natural Science Foundation of China (No. 61804079, No. 61874059, No. 21671167, No. 61904087), the Natural Science Foundation of Jiangsu Province (18KJD510005, CZ1060619001, SZDG2018007), the Science Research Funds for Nanjing University of Posts and Telecommunications (NY218110, NY217116, NY219014, BK20191202, KFJJ20170101).

Conflicts of Interest: The authors declare no conflict of interest.

\section{References}

1. Xue, M.; Xu, Z. Application of Life Cycle Assessment on Electronic Waste Management: A Review. Environ. Manag. 2017, 59, 693-707. [CrossRef]

2. Yu, X.; Shou, W.; Mahajan, B.K.; Huang, X.; Pan, H. Materials, processes, and facile manufacturing for bioresorbable electronics: A review. Adv. Mater. 2018, 30, 1707624. [CrossRef]

3. Kim, D.-H.; Kim, Y.-S.; Amsden, J.; Panilaitis, B.; Kaplan, D.L.; Omenetto, F.G.; Zakin, M.R.; Rogers, J.A. Silicon electronics on silk as a path to bioresorbable, implantable devices. Appl. Phys. Lett. 2009, 95, 133701. [CrossRef] [PubMed]

4. Hwang, S.W.; Tao, H.; Kim, D.H.; Cheng, H.; Song, J.K.; Rill, E.; Brenckle, M.A.; Panilaitis, B.; Won, S.M.; Kim, Y.S.; et al. A physically transient form of silicon electronics. Science 2012, 337, 1640-1644. [CrossRef] [PubMed]

5. Yin, L.; Cheng, H.; Mao, S.; Haasch, R.; Liu, Y.; Xie, X.; Hwang, S.-W.; Jain, H.; Kang, S.-K.; Su, Y.; et al. Dissolvable Metals for Transient Electronics. Adv. Funct. Mater. 2014, 24, 645-658. [CrossRef] 
6. Li, R.; Wang, L.; Kong, D.; Yin, L. Recent progress on biodegradable materials and transient electronics. Bioact. Mater. 2018, 3, 322-333. [CrossRef]

7. Fu, K.K.; Wang, Z.; Dai, J.; Carter, M.; Hu, L. Transient Electronics: Materials and Devices. Chem. Mater. 2016, 28, 3527-3539. [CrossRef]

8. Liu, D.; Yin, Y.; Cheng, H. Physically transient memristor based on the permeation of water at the interface of electrode and substrate. J. Alloy. Compd. 2019, 810, 151957. [CrossRef]

9. Hwang, S.W.; Song, J.K.; Huang, X.; Cheng, H.; Kang, S.K.; Kim, B.H.; Kim, J.H.; Yu, S.; Huang, Y.; Rogers, J.A. High-performance biodegradable/transient electronics on biodegradable polymers. Adv. Mater. 2014, 26, 3905-3911. [CrossRef]

10. Irimia-Vladu, M. Green electronics: Biodegradable and biocompatible materials and devices for sustainable future. Chem. Soc. Rev. 2014, 43, 588-610. [CrossRef]

11. Kang, S.K.; Koo, J.; Lee, Y.K.; Rogers, J.A. Advanced Materials and Devices for Bioresorbable Electronics. Acc. Chem. Res. 2018, 51, 988-998. [CrossRef] [PubMed]

12. Yuming, W.; Alfred, W. An Introduction to Physics and Technology of Thin Films; World Scientific: Singapore, 1994.

13. Wuttig, M.; Kanel, H. Physics and Technology Of Thin Films, Iwtf 2003-Proceedings of The International Workshop; World Scientific: Singapore, 2004.

14. Eason, R. Pulsed Laser Deposition of Thin Films: Applications-Led Growth of Functional Materials; John Wiley \& Sons: Hoboken, NJ, USA, 2007.

15. Zhang, Y.; Li, L.; Su, H.; Huang, W.; Dong, X. Binary metal oxide: Advanced energy storage materials in supercapacitors. J. Mater. Chem. A 2015, 3, 43-59. [CrossRef]

16. Kang, S.-K.; Hwang, S.-W.; Cheng, H.; Yu, S.; Kim, B.H.; Kim, J.-H.; Huang, Y.; Rogers, J.A. Dissolution Behaviors and Applications of Silicon Oxides and Nitrides in Transient Electronics. Adv. Funct. Mater. 2014, 24, 4427-4434. [CrossRef]

17. Comini, E.; Ferroni, M.; Guidi, V.; Faglia, G.; Martinelli, G.; Sberveglieri, G. Nano-structured mixed oxides compounds for gas sensing applications. Sensor. Actuator B Chem. 2002, 84, 26-32. [CrossRef]

18. Novoselov, S.K. Electric Field Effect in Atomically Thin Carbon Films. Science 2004, 306, 666-669. [CrossRef]

19. McDonnell, S.J.; Wallace, R.M. Atomically-thin layered films for device applications based upon 2D TMDC materials. Thin Solid Films 2016, 616, 482-501. [CrossRef]

20. Berzina, T.; Erokhina, S.; Camorani, P.; Konovalov, O.; Erokhin, V.; Fontana, M.P. Electrochemical control of the conductivity in an organic memristor: A time-resolved X-ray fluorescence study of ionic drift as a function of the applied voltage. ACS Appl. Mater. Interfaces 2009, 1, 2115-2118. [CrossRef]

21. Bettinger, C.J.; Bao, Z. Organic thin-film transistors fabricated on resorbable biomaterial substrates. Adv. Mater. 2010, 22, 651-655. [CrossRef]

22. Luan, L.; Royal, M.W.; Evans, R.; Fair, R.B.; Jokerst, N.M. Chip Scale Optical Microresonator Sensors Integrated With Embedded Thin Film Photodetectors on Electrowetting Digital Microfluidics Platforms. IEEE Sens. J. 2012, 12, 1794-1800. [CrossRef]

23. Koppens, F.H.; Mueller, T.; Avouris, P.; Ferrari, A.C.; Vitiello, M.S.; Polini, M. Photodetectors based on graphene, other two-dimensional materials and hybrid systems. Nat. Nanotechnol. 2014, 9, 780-793. [CrossRef]

24. Hu, L.; Choi, J.W.; Yang, Y.; Jeong, S.; La Mantia, F.; Cui, L.-F.; Cui, Y. Highly conductive paper for energy-storage devices. Proc. Natl. Acad. Sci. USA 2009, 106, 21490-21494. [CrossRef] [PubMed]

25. Bao, D.H. Transition metal oxide thin films for nonvolatile resistive random access memory applications. J. Ceram. Soc. Jpn. 2009, 117, 929-934. [CrossRef]

26. Klasens, H.A.; Koelmans, H. A tin oxide field-effect transistor. Solid State Electron. 1964, 7, 701-702. [CrossRef]

27. Koezuka, H.; Tsumura, A.; Ando, T. Field-effect transistor with polythiophene thin film. Synthetic Met. 1987, 18, 699-704. [CrossRef]

28. Wasa, K.; Kitabatake, M.; Adachi, H. Thin Film Materials Technology: Sputtering of Control Compound Materials; Springer Science \& Business Media: Berlin/Heidelberg, Germany, 2004.

29. Loh, K.J.; Kim, J.; Lynch, J.P.; Kam, N.W.S.; Kotov, N.A. Multifunctional layer-by-layer carbon nanotube-polyelectrolyte thin films for strain and corrosion sensing. Smart Mater. Struct. 2007, 16, 429-438. [CrossRef]

30. Ling, M.M.; Bao, Z. Thin Film Deposition, Patterning, and Printing in Organic Thin Film Transistors. Chem. Mater. 2004, 16, 4824-4840. [CrossRef] 
31. Freund, L.B.; Suresh, S. Thin Film Materials: Stress, Defect Formation and Surface Evolution; Cambridge University Press: Cambridge, UK, 2004.

32. Böer, K.W. Handbook of the Physics of Thin-Film Solar Cells; Springer Science \& Business: Berlin/Heidelberg, Germany, 2014.

33. Hu, X.; Li, G.; Yu, J.C. Design, fabrication, and modification of nanostructured semiconductor materials for environmental and energy applications. Langmuir 2010, 26, 3031-3039. [CrossRef]

34. Anasori, B.; Lukatskaya, M.R.; Gogotsi, Y. 2D metal carbides and nitrides (MXenes) for energy storage. Nat. Rev. Mater. 2017, 2, 16098. [CrossRef]

35. Wisitsoraat, A.; Tuantranont, A.; Patthanasettakul, V.; Lomas, T.; Chindaudom, P. Ion-assisted e-beam evaporated gas sensor for environmental monitoring. Sci. Technol. Adv. Mater. 2005, 6, 26. [CrossRef]

36. Baraton, M.-I. Sensors for Environment, Health and Security: Advanced Materials and Technologies; Springer Science \& Business Media: Dordrecht, The Netherlands, 2008.

37. Boyadjiev, S.; Georgieva, V.; Vergov, L.; Szilágyi, I.M. QCM gas sensor characterization of ALD-grown very thin $\mathrm{TiO}_{2}$ films. J. Phys. Conf. Ser. 2018, 992, 012054. [CrossRef]

38. Mannion, J.M.; Locklair, W.D.; Powell, B.A.; Husson, S.M. Alpha spectroscopy substrates based on thin polymer films. J. Radioanal. Nucl. Chem. 2015, 307, 2339-2345. [CrossRef]

39. Yang, G.; Jung, W.; Ahn, S.-J.; Lee, D. Controlling the Oxygen Electrocatalysis on Perovskite and Layered Oxide Thin Films for Solid Oxide Fuel Cell Cathodes. Appl. Sci. 2019, 9, 1030. [CrossRef]

40. Hwang, S.-W.; Lee, C.H.; Cheng, H.; Jeong, J.-W.; Kang, S.-K.; Kim, J.-H.; Shin, J.; Yang, J.; Liu, Z.; Ameer, G.A. Biodegradable elastomers and silicon nanomembranes/nanoribbons for stretchable, transient electronics, and biosensors. Nano Lett. 2015, 15, 2801-2808. [CrossRef] [PubMed]

41. Treiser, M.; Abramson, S.; Langer, R.; Kohn, J. Degradable and Resorbable Biomaterials. In Biomaterials Science: An Introduction to Materials, 3rd ed.; Elsevier Inc.: Amsterdam, The Netherlands, 2013; pp. 179-195.

42. Dagdeviren, C.; Hwang, S.W.; Su, Y.; Kim, S.; Cheng, H.; Gur, O.; Haney, R.; Omenetto, F.G.; Huang, Y.; Rogers, J.A. Transient, biocompatible electronics and energy harvesters based on ZnO. Small 2013, 9, 3398-3404. [CrossRef]

43. Martin, C.; Kostarelos, K.; Prato, M.; Bianco, A. Biocompatibility and biodegradability of 2D materi-als: Graphene and beyond. Chem. Commun. 2019, 55, 5540-5546. [CrossRef]

44. Kern, W. Thin Film Processes II; Elsevier: Amsterdam, The Netherlands, 2012.

45. Petty, M.C. Organic Thin Film Deposition Techniques. Encycl. Nanosci. Nanotechnol. 2004, 8, $295-304$. [CrossRef]

46. Gong, D.; Grimes, C.A.; Varghese, O.K.; Hu, W.; Singh, R.S.; Chen, Z.; Dickey, E.C. Titanium oxide nanotube arrays prepared by anodic oxidation. J. Mater. Res. 2001, 16, 3331-3334. [CrossRef]

47. Jung, H.Y.; Oh, S.C.; Lee, H. Resistive Switching Characteristics and Failure Analysis of $\mathrm{TiO}_{2} \mathrm{Thin}^{\mathrm{Film}}$ Deposited by RF Magnetron Sputtering System. J. Electrochem. Soc. 2011, 158, H178-H182. [CrossRef]

48. Pan, C.; Ma, T. High-quality transparent conductive indium oxide films prepared by thermal evaporation. Appl. Phys. Lett. 1980, 37, 163-165. [CrossRef]

49. Al-Kuhaili, M.F. Characterization of copper oxide thin films deposited by the thermal evaporation of cuprous oxide $\left(\mathrm{Cu}_{2} \mathrm{O}\right)$. Vacuum 2008, 82, 623-629. [CrossRef]

50. Markeev, A.; Chouprik, A.; Egorov, K.; Lebedinskii, Y.; Zenkevich, A.; Orlov, O. Multilevel resistive switching in ternary $\mathrm{Hf}_{\mathrm{x}} \mathrm{Al}_{1-\mathrm{x}} \mathrm{O}_{\mathrm{y}}$ oxide with graded $\mathrm{Al}$ depth profile. Microelectron. Eng. 2013, 109, 342-345. [CrossRef]

51. Wang, J.; Neaton, J.B.; Zheng, H.; Nagarajan, V.; Ogale, S.B.; Liu, B.; Viehland, D.; Vaithyanathan, V.;

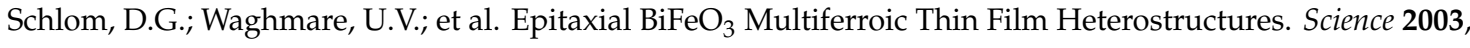
299, 1719-1722. [CrossRef] [PubMed]

52. Lu, B.; Lu, Y.; Zhu, H.; Zhang, J.; Yue, S.; Li, S.; Zhuge, F.; Ye, Z.; Lu, J. Memristors based on amorphous ZnSnO films. Mater. Lett. 2019, 249, 169-172. [CrossRef]

53. Dhahri, R.; Hjiri, M.; El Mir, L.; Alamri, H.; Bonavita, A.; Iannazzo, D.; Leonardi, S.G.; Neri, G. CO sensing characteristics of In-doped ZnO semiconductor nanoparticles. J. Sci. Adv. Mater. Devices 2017, 2, 34-40. [CrossRef]

54. Lee, S.; Kim, T.; Jang, B.; Lee, W.-Y.; Song, K.; Kim, H.; Do, G.; Hwang, S.; Chung, S.; Jang, J. Impact of Device Area and Film Thickness on Performance of Sol-gel Processed $\mathrm{ZrO}_{2}$ RRAM. IEEE Electron Device Lett. 2018, 39, 668-671. [CrossRef] 
55. Novoselov, K.S.; Mishchenko, A.; Carvalho, A.; Castro Neto, A.H. 2D materials and van der Waals heterostructures. Science 2016, 353, aac9439. [CrossRef]

56. Late, D.J.; Shaikh, P.A.; Khare, R.; Kashid, R.V.; Chaudhary, M.; More, M.A.; Ogale, S.B. Pulsed Laser-Deposited $\mathrm{MoS}_{2}$ Thin Films on W and Si: Field Emission and Photoresponse Studies. ACS Appl. Mater. Interfaces 2014, 6, 15881-15888. [CrossRef]

57. Poh, S.M.; Tan, S.J.R.; Wang, H.; Song, P.; Abidi, I.H.; Zhao, X.; Dan, J.; Chen, J.; Luo, Z.; Pennycook, S.J.; et al. Molecular-Beam Epitaxy of Two-Dimensional $\mathrm{In}_{2} \mathrm{Se}_{3}$ and Its Giant Electroresistance Switching in Ferroresistive Memory Junction. Nano Lett. 2018, 18, 6340-6346. [CrossRef]

58. Luo, G.; Zhang, Z.-Z.; Li, H.-O.; Song, X.-X.; Deng, G.-W.; Cao, G.; Xiao, M.; Guo, G.-P. Quantum dot behavior in transition metal dichalcogenides nanostructures. Front. Phys. Beijing 2017, 12, 128502. [CrossRef]

59. Upadhyay, R.K.; Soin, N.; Bhattacharya, G.; Saha, S.; Barman, A.; Roy, S.S. Grape extract assisted green synthesis of reduced graphene oxide for water treatment application. Mater. Lett. 2015, 160, 355-358. [CrossRef]

60. Hao, L.; Wang, H.; Chen, R. Organic-inorganic hybrid hydrophobic $\mathrm{Mg}(\mathrm{OH})_{2-\mathrm{x}} \mathrm{F}_{\mathrm{x}}-\mathrm{MTES}$ coating with ultraviolet durability and high visible transmittance. J. Mater. Sci. 2019, 54, 13569-13578. [CrossRef]

61. Macedo, A.G.; Christopholi, L.P.; Gavim, A.E.X.; de Deus, J.F.; Teridi, M.A.M.; Yusoff, A.R.; da Silva, W.J. Perylene derivatives for solar cells and energy harvesting: A review ofmaterials, challenges and advances. J. Mater. Sci. Mater. Electron. 2019, 30, 15803-15824. [CrossRef]

62. Pal, R.K.; Farghaly, A.A.; Wang, C.; Collinson, M.M.; Kundu, S.C.; Yadavalli, V.K. Conducting polymer-silk biocomposites for flexible and biodegradable electrochemical sensors. Biosens. Bioelectron. 2016, 81, $294-302$. [CrossRef] [PubMed]

63. Flores-Castañeda, M.; González, E.C.; Ruiz-Aguilar, I.; Camps, E.; Cruces, M.P.; Pimentel, E.; Camacho-López, M. Preparation and characterization of organic nanoparticles by laser ablation in liquids technique and their biological activity. Mater. Res. Express. 2019, 6, 1-11. [CrossRef]

64. Alvarez-Venicio, V.; Arcos-Ramos, R.O.; Hernandez-Rojas, J.A.; Guerra-Pulido, J.O.; Basiuk, V.A.; Rivera, M.; Carreon-Castro, M.D.P. Preparation and Characterization of a Novel Organic Semiconductor Indacenedithiophene Derivative and the Corresponding Langmuir-Blodgett Thin Films. J. Nanosci. Nanotechnol. 2019, 19, 7244-7250. [CrossRef]

65. You, M.; Li, W.; Pan, Y.; Fei, P.; Wang, H.; Zhang, W.; Zhi, L.; Meng, J. Preparation and characterization of antibacterial polyamine-based cyclophosphazene nanofiltration membranes. J. Membr. Sci. 2019, 592, 1-11. [CrossRef]

66. Yuan, Y.; Giri, G.; Ayzner, A.L.; Zoombelt, A.P.; Mannsfeld, S.C.B.; Chen, J.; Nordlund, D.; Toney, M.F.; Huang, J.; Bao, Z. Ultra-high mobility transparent organic thin film transistors grown by an off-centre spin-coating method. Nat. Commun. 2014, 5, 3005. [CrossRef]

67. Lewis, G.D.A.; Zhang, Y.; Schlenker, C.W.; Ryu, K.; Thompson, M.E.; Zhou, C. Continuous, Highly Flexible, and Transparent Graphene Films by Chemical Vapor Deposition for Organic Photovoltaics. ACS Nano 2010, 4, 2865-2873. [CrossRef]

68. Seul, M.; Sammon, M.J. Preparation of surfactant multilayer films on solid substrates by deposition from organic solution. Thin Solid Films 1990, 185, 287-305. [CrossRef]

69. Mohammed, M.G.; Kramer, R. All-Printed Flexible and Stretchable Electronics. Adv. Mater. 2017, $29,1604965$. [CrossRef]

70. Inui, T.; Mandamparambil, R.; Araki, T.; Abbel, R.; Koga, H.; Nogi, M.; Suganuma, K. Laser-induced forward transfer of high-viscosity silver precursor ink for non-contact printed electronics. RSC Adv. 2015, 5, 77942-77947. [CrossRef]

71. Mandal, S.; Purohit, G.; Katiyar, M. Inkjet Printed Organic Thin Film Transistors: Achievements and Challenges. Mater. Sci. Forum 2013, 736, 250-274. [CrossRef]

72. Feig, V.R.; Tran, H.; Bao, Z. Biodegradable Polymeric Materials in Degradable Electronic Devices. ACS Central Sci. 2018, 4, 337-348. [CrossRef] [PubMed]

73. Hwang, S.W.; Park, G.; Cheng, H.; Song, J.K.; Kang, S.K.; Yin, L.; Kim, J.H.; Omenetto, F.G.; Huang, Y.; Lee, K.M.; et al. 25th anniversary article: Materials for high-performance biodegradable semiconductor devices. Adv. Mater. 2014, 26, 1992-2000. [CrossRef]

74. Li, W.; Wang, Z.; Deschler, F.; Gao, S.; Friend, R.H.; Cheetham, A.K. Chemically diverse and multifunctional hybrid organic-inorganic perovskites. Nat. Rev. Mater. 2017, 2, 16099. [CrossRef] 
75. Kang, S.-K.; Hwang, S.-W.; Yu, S.; Seo, J.-H.; Corbin, E.A.; Shin, J.; Wie, D.S.; Bashir, R.; Ma, Z.; Rogers, J.A. Biodegradable Thin Metal Foils and Spin-On Glass Materials for Transient Electronics. Adv. Funct. Mater. 2015, 25, 1789-1797. [CrossRef]

76. Rudraswamy, S.B.; Bhat, N. Optimization of RF Sputtered Ag-Doped $\mathrm{BaTiO}_{3}-\mathrm{CuO}$ Mixed Oxide Thin Film as Carbon Dioxide Sensor for Environmental Pollution Monitoring Application. IEEE Sens. J. 2016, 16, 5145-5151. [CrossRef]

77. Zhuang, Y.; Yuan, W.; Qian, L.; Chen, S.; Shi, G. High-performance gas sensors based on a thiocy-anate ion-doped organometal halide perovskite. Phys. Chem. Chem. Phys. 2017, 19, 12876-12881. [CrossRef]

78. Kazim, S.; Nazeeruddin, M.K.; Gratzel, M.; Ahmad, S. Perovskite as light harvester: A game changer in photovoltaics. Angew. Chem. Int. Edit. 2014, 53, 2812-2824. [CrossRef]

79. Cheng, X.-F.; Qian, W.-H.; Wang, J.; Yu, C.; He, J.-H.; Li, H.; Xu, Q.-F.; Chen, D.-Y.; Li, N.-J.; Lu, J.-M. Environmentally Robust Memristor Enabled by Lead-Free Double Perovskite for High-Performance Information Storage. Small 2019, 1905731. [CrossRef]

80. Lin, Q.; Hu, W.; Zang, Z.; Zhou, M.; Du, J.; Wang, M.; Han, S.; Tang, X. Transient Resistive Switc-hing Memory of $\mathrm{CsPbBr}_{3}$ Thin Films. Adv. Electron. Mater. 2018, 4, 1700596. [CrossRef]

81. Chen, R.; Xu, J.; Lao, M.; Liang, Z.; Chen, Y.; Zhong, C.; Huang, L.; Hao, A.; Ismail, M. Transient Resistive Switching for Nonvolatile Memory Based on Water-Soluble $\mathrm{Cs}_{4} \mathrm{PbBr}_{6}$ Perovskite Films. Phys. Status. Solidi.-R 2019, 13, 1-7. [CrossRef]

82. Chen, Y.; Song, J.; Wu, Y.; Ding, S.; Hou, P.; Song, H.; Wang, J.; Zhong, X. The resistive switchingbehaviors of a flexible device based on $\mathrm{SrTiO}_{3}$ film. EPL-Europhys. Lett. 2019, 127, 1-6. [CrossRef]

83. Li, J.; Singh, V.V.; Sattayasamitsathit, S.; Orozco, J.; Kaufmann, K.; Dong, R.; Gao, W.; Jurado-Sanchez, B.; Fedorak, Y.; Wang, J. Water-Driven Micromotors for Rapid Photocatalytic Degradation of Biological and Chemical Warfare Agents. ACS Nano 2014, 8, 11118-11125. [CrossRef]

84. Linsebigler, A.L.; Lu, G.; Yates, J.T. Photocatalysis on $\mathrm{TiO}_{2}$ Surfaces: Principles, Mechanisms, and Selected Results. Chem. Rev. 1995, 95, 735-758. [CrossRef]

85. Hoffmann, M.R.; Martin, S.T.; Choi, W.; Bahnemann, D.W. Environmental Applications of Semiconductor Photocatalysis. Chem. Rev. 1995, 95, 69-96. [CrossRef]

86. Gupta, S.K.; Joshi, A.; Kaur, M. Development of gas sensors using ZnO nanostructures. J. Chem. Sci. 2010, 122, 57-62. [CrossRef]

87. Arya, S.K.; Saha, S.; Ramirez-Vick, J.E.; Gupta, V.; Bhansali, S.; Singh, S.P. Recent advances in ZnO nanostructures and thin films for biosensor applications: Review. Anal. Chim. Acta 2012, 737, 1-21. [CrossRef]

88. Bhat, S.S.; Qurashi, A.; Khanday, F.A. ZnO nanostructures based biosensors for cancer and infectious disease applications: Perspectives, prospects and promises. TrAC Trend. Anal. Chem. 2017, 86, 1-13. [CrossRef]

89. Wang, Z.L. Zinc oxide nanostructures: Growth, properties and applications. J. Phys. Condens. Mater. 2004, 16, R829-R858. [CrossRef]

90. Xu, N.; Liu, L.; Sun, X.; Liu, X.; Han, D.; Wang, Y.; Han, R.; Kang, J.; Yu, B. Characteristics and mechanism of conduction/set process in TiN/ZnO/Pt resistance switching random-access memories. Appl. Phys. Lett. 2008, 92, 232112. [CrossRef]

91. Park, S.Y.; Jung, Y.W.; Hwang, S.H.; Jang, G.H.; Seo, H.; Kim, Y.-C.; Ok, M.-R. Instrument-Free and Autonomous Generation of $\mathrm{H}_{2} \mathrm{O}_{2}$ from $\mathrm{Mg}-\mathrm{ZnO} / \mathrm{Au}$ Hybrids for Disinfection and Organic Pollutant Degradations. Met. Mater. Int. 2018, 24, 657-663. [CrossRef]

92. Hunge, Y.M.; Yadav, A.A.; Kulkarni, S.B.; Mathe, V.L. A multifunctional ZnO thin film based devices for photoelectrocatalytic degradation of terephthalic acid and $\mathrm{CO}_{2}$ gas sensing applications. Sensor. Actuator $B$ Chem. 2018, 274, 1-9. [CrossRef]

93. Liu, G.; Rumyantsev, S.L.; Jiang, C.; Shur, M.S.; Balandin, A.A. Selective Gas Sensing With h-BN Capped $\mathrm{MoS}_{2}$ Heterostructure Thin-Film Transistors. IEEE Electron Device Lett. 2015, 36, 1202-1204. [CrossRef]

94. Juliasih, N.; Buchari; Noviandri, I. Application of ZnO Nanoparticle as Sulphide Gas Sensor Using UV/VIS/NIR-Spectrophotometer. J. Phys. Conf. Ser. 2017, 824, 012020. [CrossRef]

95. Buvailo, A.I.; Xing, Y.; Hines, J.; Dollahon, N.; Borguet, E. $\mathrm{TiO}_{2} / \mathrm{LiCl}$-based nanostructured thin film for humidity sensor applications. ACS Appl. Mater. Interfaces 2011, 3, 528-533. [CrossRef] 
96. Park, J.I.; Jang, Y.; Bae, J.S.; Yoon, J.H.; Lee, H.U.; Wakayama, Y.; Kim, J.P.; Jeong, Y. Effect of thicknessdependent structural defects on electrical stability of $\mathrm{MoS}_{2}$ thin film transistors. J. Alloys Compd. 2020, 814, 152134. [CrossRef]

97. Lee, B.Y.; Kim, D.H.; Park, J.; Park, K.I.; Lee, K.J.; Jeong, C.K. Modulation of surface physics and chemistry in triboelectric energy harvesting technologies. Sci. Technol. Adv. Mater. 2019, 20, 758-773. [CrossRef]

98. Barai, H.R.; Rahman, M.M.; Roy, M.; Barai, P.; Joo, S.W. A calcium doped binary strontium-copper oxide electrode material for high-performance supercapacitors. Mater. Sci. Semicond. Proc. 2019, 90, 245-251. [CrossRef]

99. Yang, L.F.; Zhao, Y.G.; Zhang, S.; Li, P.S.; Gao, Y.; Yang, Y.J.; Huang, H.L.; Miao, P.X.; Liu, Y.; Chen, A.T.; et al. Bipolar loop-like non-volatile strain in the (001)-oriented $\mathrm{Pb}\left(\mathrm{Mg}_{1 / 3} \mathrm{Nb}_{2 / 3}\right) \mathrm{O}_{3}-\mathrm{PbTiO}_{3}$ single crystals. Sci. Rep. UK 2014, 4, 1-7. [CrossRef]

100. Song, F.; Wang, H.; Sun, J.; Dang, B.; Gao, H.; Yang, M.; Ma, X.; Hao, Y. Solution-Processed Physi-cally Transient Resistive Memory Based on Magnesium Oxide. IEEE Electron Device Lett. 2019, 40, $193-195$. [CrossRef]

101. Rhee, S.J.; Kang, C.Y.; Choi, C.H.; Zhang, M.; Lee, J.C. Material and electrical analysis of hafnium titania bilayer dielectric metal-oxide-semiconductor field-effect transistors. J. Vac. Sci. Technol. B 2005, 23, 2561-2563. [CrossRef]

102. Xie, D.; Jiang, J.; Hu, W.; He, Y.; Yang, J.; He, J.; Gao, Y.; Wan, Q. Coplanar Multigate MoS $_{2}$ Electric-Double-Layer Transistors for Neuromorphic Visual Recognition. ACS Appl. Mater. Interfaces 2018, 10, 25943-25948. [CrossRef] [PubMed]

103. Lee, S.Y. Improvement on the Stability of Amorphous Indium Gallium Zinc Oxide Thin Film Transistors Using Amorphous Oxide Multilayer Source/Drain Electrodes. Trans. Electr. Electron. Mater. 2016, 17, 143-145. [CrossRef]

104. Wang, J.T.; Liu, Y.F.; Chen, X.T.; Chen, C.; Chen, P.; Wang, Z.K.; Duan, Y. Functional Metal Oxides in Perovskite Solar Cells. ChemPhysChem 2019, 20, 2580-2586. [CrossRef]

105. Jin, S.H.; Kang, S.K.; Cho, I.T.; Han, S.Y.; Chung, H.U.; Lee, D.J.; Shin, J.; Baek, G.W.; Kim, T.I.; Lee, J.H.; et al. Water-Soluble Thin Film Transistors and Circuits Based on Amorphous Indium-Gallium-Zinc Oxide. ACS Appl. Mater. Interfaces 2015, 7, 8268-8274. [CrossRef]

106. Kim, T.W.; Cho, W.J. Effects of Al Addition on Resistive-Switching Characteristics of Solution Processed Zn-Sn-O ReRAMs. J. Nanosci. Nanotechnol. 2019, 19, 6099-6105. [CrossRef]

107. Barman, A.; Kar-Narayan, S.; Mukherjee, D. Caloric Effects in Perovskite Oxides. Adv. Mater. Interfaces 2019, 6, 1-31. [CrossRef]

108. Raza, E.; Aziz, F.; Ahmad, Z. Stability of organometal halide perovskite solar cells and role of HTMs: Recent developments and future directions. RSC Adv. 2018, 8, 20952-20967. [CrossRef]

109. Kaji, H.; Kondo, H.; Fujii, T.; Arita, M.; Takahashi, Y. Effect of Electrode and Interface Oxide on the Property of ReRAM Composed of $\operatorname{Pr}_{0.7} \mathrm{Ca}_{0.3} \mathrm{MnO}_{3}$. In IOP Conference Series: Materials Science and Engineering; IOP Publishing: Bristol, UK, 2010; p. 012032.

110. Janousch, M.; Meijer, G.I.; Staub, U.; Delley, B.; Karg, S.F.; Andreasson, B.P. Role of oxygen vac-ancies in Cr-doped $\mathrm{SrTiO}_{3}$ for resistance-change memory. Adv. Mater. 2007, 19, 2232-2235. [CrossRef]

111. Mirzababaei, J.; Chuang, S. $\mathrm{La}_{0.6} \mathrm{Sr}_{0.4} \mathrm{Co}_{0.2} \mathrm{Fe}_{0.8} \mathrm{O}_{3}$ Perovskite: A Stable Anode Catalyst for Direct Methane Solid Oxide Fuel Cells. Catalysts 2014, 4, 146-161. [CrossRef]

112. Muralt, P.; Polcawich, R.G.; Trolier-McKinstry, S. Piezoelectric Thin Films for Sensors, Actuators, and Energy Harvesting. MRS Bull. 2009, 34, 658-664. [CrossRef]

113. Todaro, M.T.; Guido, F.; Algieri, L.; Mastronardi, V.M.; Desmaele, D.; Epifani, G.; De Vittorio, M. Biocompatible, Flexible, and Compliant Energy Harvesters Based on Piezoelectric Thin Films. IEEE. Trans. Nanotechnol. 2018, 17, 220-230. [CrossRef]

114. Chen, D.; Chen, X. Luminescent perovskite quantum dots: Synthesis, microstructures, optical properties and applications. J. Mater. Chem. C 2019, 7, 1413-1446. [CrossRef]

115. Zhang, X.; Yang, H.; Jiang, Z.; Zhang, Y.; Wu, S.; Pan, H.; Khisro, N.; Chen, X. Photoresponse of nonvolatile resistive memory device based on all-inorganic perovskite $\mathrm{CsPbBr}_{3}$ nanocrystals. J. Phys. D Appl. Phys. 2019, 52, 1-7. [CrossRef] 
116. Liu, D.; Lin, Q.; Zang, Z.; Wang, M.; Wangyang, P.; Tang, X.; Zhou, M.; Hu, W. Flexible All-Inorganic Perovskite $\mathrm{CsPbBr}_{3}$ Nonvolatile Memory Device. ACS Appl. Mater. Interfaces 2017, 9, 6171-6176. [CrossRef] [PubMed]

117. Liu, X.; Hersam, M.C. 2D materials for quantum information science. Nat. Rev. Mater. 2019, 4, 669-684. [CrossRef]

118. Fiori, G.; Bonaccorso, F.; Iannaccone, G.; Palacios, T.; Neumaier, D.; Seabaugh, A.; Banerjee, S.K.; Colombo, L. Electronics based on two-dimensional materials. Nat. Nanotechnol. 2014, 9, 768-779. [CrossRef]

119. Coleman, J.N.; Lotya, M.; O’Neill, A.; Bergin, S.D.; King, P.J.; Khan, U.; Young, K.; Gaucher, A.; De, S.; Smith, R.J. Two-Dimensional Nanosheets Produced by Liquid Exfoliation of Layered Materials. Science 2011, 331, 568-571. [CrossRef]

120. Xia, F.; Wang, H.; Xiao, D.; Dubey, M.; Ramasubramaniam, A. Two-dimensional material nanophotonics. Nat. Photonics. 2014, 8, 899-907. [CrossRef]

121. Akinwande, D.; Petrone, N.; Hone, J. Two-dimensional flexible nanoelectronics. Nat. Commun. 2014, 5, 5678. [CrossRef] [PubMed]

122. Cepellotti, A.; Fugallo, G.; Paulatto, L.; Lazzeri, M.; Mauri, F.; Marzari, N. Phonon hydrodynamics in two-dimensional materials. Nat. Commun. 2015, 6, 6400. [CrossRef] [PubMed]

123. Doussal, P.L.; Radzihovsky, L. Self-consistent theory of polymerized membranes. Phys. Rev. Lett. 1992, 69, 1209-1212. [CrossRef] [PubMed]

124. Büchner, C.; Wang, Z.-J.; Burson, K.M.; Willinger, M.G.; Heyde, M.; Schloegl, R.; Freund, H.-J. A Large-Area Transferable Wide Band Gap 2D Silicon Dioxide Layer. ACS Nano 2016, 10, 7982-7989. [CrossRef]

125. Cassabois, G.; Valvin, P.; Gil, B. Hexagonal boron nitride is an indirect bandgap semiconductor. Nat. Photon. 2016, 10, 262-266. [CrossRef]

126. Splendiani, A.; Sun, L.; Zhang, Y.; Li, T.; Kim, J. Emerging Photoluminescence in Monolayer MoS 2 . Nano Lett. 2010, 10, 1271-1275. [CrossRef]

127. Naguib, M.; Kurtoglu, M.; Presser, V.; Lu, J.; Niu, J.; Heon, M.; Hultman, L.; Gogotsi, Y.; Barsoum, M.W. Two-Dimensional Nanocrystals Produced by Exfoliation of $\mathrm{Ti}_{3} \mathrm{AlC}_{2}$. Adv. Mater. 2011, 23, 4248-4253. [CrossRef]

128. Naguib, M.; Mashtalir, O.; Carle, J.; Presser, V.; Lu, J.; Hultman, L.; Gogotsi, Y.; Barsoum, M.W. Two-Dimensional Transition Metal Carbides. ACS Nano 2012, 6, 1322-1331. [CrossRef]

129. Naguib, M.; Halim, J.; Lu, J.; Cook, K.M.; Hultman, L.; Gogotsi, Y.; Barsoum, M.W. New two- dimensional niobium and vanadium carbides as promising materials for Li-ion batteries. J. Am. Chem. Soc. 2013, 135, 15966-15969. [CrossRef]

130. Khazaei, M.; Arai, M.; Sasaki, T.; Chung, C.-Y.; Venkataramanan, N.S.; Estili, M.; Sakka, Y.; Kawazoe, Y. Novel Electronic and Magnetic Properties of Two-Dimensional Transition Metal Carbides and Nitrides. Adv. Funct. Mater. 2013, 23, 2185-2192. [CrossRef]

131. Ghidiu, M.; Naguib, M.; Shi, C.; Mashtalir, O.; Pan, L.; Zhang, B.; Yang, J.; Gogotsi, Y.; Billinge, S.J.; Barsoum, M.W. Synthesis and characterization of two-dimensional $\mathrm{Nb}_{4} \mathrm{C}_{3}$ (MXene). Chem. Commun. 2014, 50, 9517-9520. [CrossRef] [PubMed]

132. Anasori, B.; Xie, Y.; Beidaghi, M.; Lu, J.; Barsoum, M.W. Two-Dimensional, Ordered, Double Tran-sition Metals Carbides (MXenes). ACS Nano 2015, 9, 9507-9516. [CrossRef] [PubMed]

133. Gogotsi, Y. Chemical vapour deposition: Transition metal carbides go 2D. Nat. Mater. 2015, 14, 1-3. [CrossRef] [PubMed]

134. Şahin, H.; Cahangirov, S.; Topsakal, M.; Bekaroglu, E.; Akturk, E.; Senger, R.T.; Ciraci, S. Monolayer honeycomb structures of group-IV elements and III-V binary compounds: First-principles calculations. Phys. Rev. B 2009, 80, 155453. [CrossRef]

135. Zhuang, H.L.; Hennig, R.G. Computational identification of single-layer CdO for electronic and optical applications. Appl. Phys. Lett. 2013, 103, 212102. [CrossRef]

136. Zheng, H.; Li, X.-B.; Chen, N.-K.; Xie, S.-Y.; Tian, W.Q.; Chen, Y.; Xia, H.; Zhang, S.B.; Sun, H.-B. Monolayer II-VI semiconductors: A first-principles prediction. Phys. Rev. B 2015, 92, 115307. [CrossRef]

137. Lebegue, S.; Eriksson, O. Electronic structure of two-dimensional crystals from ab initio theory. Phys. Rev. B 2009, 79, 115409. [CrossRef]

138. Ashton, M.; Paul, J.; Sinnott, S.B.; Hennig, R.G. Topology-Scaling Identification of Layered Solids and Stable Exfoliated 2D Materials. Phys. Rev. Lett. 2017, 118, 106101. [CrossRef] 
139. Zhou, L.; Kou, L.; Sun, Y.; Felser, C.; Frauenheim, T. New Family of Quantum Spin Hall Insulators in Two-dimensional Transition-Metal Halide with Large Nontrivial Band Gaps. Nano Lett. 2015, 15, 7867-7872. [CrossRef]

140. Debbichi, L.; Kim, H.; Björkman, T.; Eriksson, O.; Lebègue, S. First-principles investigation of two-dimensional trichalcogenide and sesquichalcogenide monolayers. Phys. Rev. B 2016, 93, 245307. [CrossRef]

141. Liu, H.; Neal, A.T.; Zhu, Z.; Luo, Z.; Xu, X.; Tománek, D.; Ye, P.D. Phosphorene: An Unexplored 2D Semiconductor with a High Hole Mobility. ACS Nano 2014, 8, 4033-4041. [CrossRef] [PubMed]

142. Park, J.; Park, S.; Ryu, S.; Bhang, S.H.; Kim, J.; Yoon, J.K.; Park, Y.H.; Cho, S.P.; Lee, S.; Hong, B.H. Graphene-regulated cardiomyogenic differentiation process of mesenchymal stem cells by enhancing the expression of extracellular matrix proteins and cell signaling molecules. Adv. Healthc. Mater. 2014, 3, 176-181. [CrossRef] [PubMed]

143. Russier, J.; Oudjedi, L.; Piponnier, M.; Bussy, C.; Prato, M.; Kostarelos, K.; Lounis, B.; Bianco, A.; Cognet, L. Direct visualization of carbon nanotube degradation in primary cells by photothermal imaging. Nanoscale 2017, 9, 4642-4645. [CrossRef] [PubMed]

144. Kotchey, G.P.; Allen, B.L.; Vedala, H.; Yanamala, N.; Kapralov, A.A.; Tyurina, Y.Y.; Klein-Seetharaman, J.; Kagan, V.E.; Star, A. The Enzymatic Oxidation of Graphene Oxide. ACS Nano 2011, 5, 2098-2108. [CrossRef]

145. Kotchey, G.P.; Hasan, S.A.; Kapralov, A.A.; Ha, S.H.; Kim, K.; Shvedova, A.A.; Kagan, V.E.; Star, A. A Natural Vanishing Act: The Enzyme-Catalyzed Degradation of Carbon Nanomaterials. Accounts Chem. Res. 2012, 45, 1770-1781. [CrossRef] [PubMed]

146. Bhattacharya, K.; Mukherjee, S.P.; Gallud, A.; Burkert, S.C.; Bistarelli, S.; Bellucci, S.; Bottini, M.; Star, A.; Fadeel, B. Biological interactions of carbon-based nanomaterials: From coronation to degradation. Nanomed. Nanotechnol. 2016, 12, 333-351. [CrossRef]

147. Garadkar, K.; Patil, A.; Hankare, P.; Chate, P.; Sathe, D.; Delekar, S. $\mathrm{MoS}_{2}$ : Preparation and their characterization. J. Alloys Compd. 2009, 487, 786-789. [CrossRef]

148. Ding, Y.; Wang, Y.; Ni, J.; Shi, L.; Shi, S.; Tang, W. First principles study of structural, vibrational and electronic properties of graphene-like $\mathrm{MX}_{2}(\mathrm{M}=\mathrm{Mo}, \mathrm{Nb}, \mathrm{W}, \mathrm{Ta} ; \mathrm{X}=\mathrm{S}, \mathrm{Se}, \mathrm{Te})$ monolayers. Physica B 2011, 406, 2254-2260. [CrossRef]

149. Amory, C.; Bernede, J.C.; Hamdadou, N. A study of textured non-stoichiometric MoTe 2 thin films used as substrates for textured stoichiometric $\mathrm{MoS}_{2}$ thin films. Vacuum 2004, 74, 117. [CrossRef]

150. Pütz, J.; Aegerter, M.A. Spin deposition of $\mathrm{MoS}_{x}$ thin films. Thin Solid Films 1999, 351, 119-124. [CrossRef]

151. Jäger-Waldau, A.; Lux-Steiner, M.; Jäger-Waldau, R.; Burkhardt, R.; Bucher, E. Composition and morphology of $\mathrm{MoSe}_{2}$ thin films. Thin Solid Films 1990, 189, 339-345. [CrossRef]

152. Regula, M.; Ballif, C.; Moser, J.; Levy, F. Structural, chemical, and electrical characterisation of reactively sputtered WS thin films. Thin Solid Films 1996, 280, 67-75. [CrossRef]

153. Fleischauer, P.D. Fundamental aspects of the electronic structure, materials properties and lubri-cation performance of sputtered $\mathrm{MoS}_{2}$ films. Thin Solid Films 1987, 154, 309-322. [CrossRef]

154. Delphine, S.M.; Jayachandran, M.; Sanjeeviraja, C. Pulsed electrodeposition and characterization of molybdenum diselenide thin film. Mater. Res. Bull. 2005, 40, 135-147. [CrossRef]

155. Mccain, M.N.; He, B.; Sanati, J.; Wang, Q.J.; Marks, T.J. Aerosol-Assisted Chemical Vapor Deposition of Lubricating $\mathrm{MoS}_{2}$ Films. Ferrous Substrates and Titanium Film Doping. Chem. Mater. 2013, 20, 5438-5443. [CrossRef]

156. Jiménez, D. Drift-diffusion model for single layer transition metal dichalcogenide field-effect transistors. Appl. Phys. Lett. 2012, 101, 243501. [CrossRef]

157. Cao, W.; Kang, J.; Liu, W.; Banerjee, K. A Compact Current-Voltage Model for 2D Semiconductor Based Field-Effect Transistors Considering Interface Traps, Mobility Degradation, and Inefficient Doping Effect. IEEE Trans. Electron. Devices 2014, 61, 4282-4290. [CrossRef]

158. Najam, F.; Tan, M.L.P.; Ismail, R.; Yu, Y.S. Two-dimensional (2D) transition metal dichalcogenide semiconductor field-effect transistors: The interface trap density extraction and compact model. Semicond. Sci. Technol. 2015, 30, 075010. [CrossRef]

159. Wang, Z.; von dem Bussche, A.; Qiu, Y.; Valentin, T.M.; Gion, K.; Kane, A.B.; Hurt, R.H. Chemical dissolution pathways of $\mathrm{MoS}_{2}$ nanosheets in biological and environmental media. Environ. Sci. Technol. 2016, 50, 7208-7217. [CrossRef] 
160. Ivanovskii, A.L.; Enyashin, A.N. Graphene-like transition-metal nanocarbides and nanonitrides. Russ. Chem. Rev. 2013, 82, 735-746. [CrossRef]

161. Zha, X.J.; Zhao, X.; Pu, J.H.; Tang, L.S.; Ke, K.; Bao, R.Y.; Bai, L.; Liu, Z.Y.; Yang, M.B.; Yang, W. Flexible Anti-Biofouling MXene/Cellulose Fibrous Membrane for Sustainable Solar-Driven Water Purification. ACS Appl. Mater. Interfaces 2019, 11, 36589-36597. [CrossRef] [PubMed]

162. Zhang, X.; Zhang, Z.; Zhou, Z. MXene-based materials for electrochemical energy storage. J. Energy Chem. 2018, 27, 73-85. [CrossRef]

163. Sun, S.; Chan, L.; Hafez, A.M.; Zhu, H.; Wu, S.J.C.E.J. Two-dimensional MXenes for Energy Storage. Chem. Eng. J. 2017, 338, 22-36. [CrossRef]

164. Yang, J.; Bao, W.; Jaumaux, P.; Zhang, S.; Wang, C.; Wang, G. MXene-Based Composites: Synthesis and Applications in Rechargeable Batteries and Supercapacitors. Adv. Mater. Interfaces 2019, 6, 1802004. [CrossRef]

165. Shein, I.R.; Ivanovskii, A.L. Graphene-like titanium carbides and nitrides $\mathrm{Ti}_{n+1} \mathrm{C}_{n}, \mathrm{Ti}_{\mathrm{n}+1} \mathrm{~N}_{\mathrm{n}}(\mathrm{n}=1,2$, and 3) from de-intercalated MAX phases: First-principles probing of their structural, electronic propertiesand relative stability. Comp. Mater. Sci. 2012, 65, 104-114. [CrossRef]

166. Khazaei, M.; Ranjbar, A.; Ghorbani-Asl, M.; Arai, M.; Sasaki, T.; Liang, Y.; Yunoki, S. Nearly free electron states in MXenes. Phys. Rev. B. 2016, 93, 205125. [CrossRef]

167. Kurtoglu, M.; Naguib, M.; Gogotsi, Y.; Barsoum, M.W. First principles study of two-dimensional early transition metal carbides. MRS Commun. 2012, 2, 133-137. [CrossRef]

168. Hu, Q.; Sun, D.; Wu, Q.; Wang, H.; Wang, L.; Liu, B.; Zhou, A.; He, J. MXene: A New Family of Promising Hydrogen Storage Medium. J. Phys. Chem. A 2013, 117, 14253-14260. [CrossRef]

169. Hu, Q.; Wang, H.; Wu, Q.; Ye, X.; Zhou, A.; Sun, D.; Wang, L.; Liu, B.; He, J. Two-dimensional Sc ${ }_{2}$ C: A reversible and high-capacity hydrogen storage material predicted by first-principles calculations. Int. J. Hydrog. Energy 2014, 39, 10606-10612. [CrossRef]

170. Shibata, Y.; Tsutsumi, J.y.; Matsuoka, S.; Matsubara, K.; Yoshida, Y.; Chikamatsu, M.; Hasegawa, T. Uniaxially oriented polycrystalline thin films and air-stable n-type transistors based on donor-acceptor semiconductor $\left(\mathrm{diC}_{8} \mathrm{BTBT}\right)\left(\mathrm{F}_{\mathrm{n}} \mathrm{TCNQ}\right)[\mathrm{n}=0,2,4]$. Appl. Phys. Lett. 2015, 106, 1-4. [CrossRef]

171. Yang, T.; Liang, B.; Cheng, Z.; Li, C.; Lu, G.; Wang, Y. Construction of Efficient Deep-Red/Near-Infrared Emitter Based on a Large $\pi$-Conjugated Acceptor and Delayed Fluorescence OLEDs with External Quantum Efficiency of over 20\%. J. Phys. Chem. C 2019, 123, 18585-18592. [CrossRef]

172. Wu, C.; Wu, T.; Yang, Y.; McLeod, J.A.; Wang, Y.; Zou, Y.; Zhai, T.; Li, J.; Ban, M.; Song, T.; et al. Alternative Type Two-Dimensional-Three-Dimensional Lead Halide Perovskite with Inorganic Sodium Ions as a Spacer for High-Performance Light-Emitting Diodes. ACS Nano 2019, 13, 1645-1654. [CrossRef] [PubMed]

173. Dang, B.; Wu, Q.; Song, F.; Sun, J.; Yang, M.; Ma, X.; Wang, H.; Hao, Y. A bio-inspired physically transient/biodegradable synapse for security neuromorphic computing based on memristors. Nanoscale 2018, 10, 20089-20095. [CrossRef] [PubMed]

174. Salzillo, T.; Campos, A.; Mas-Torrent, M. Solution-processed thin films of a charge transfer complex for ambipolar field-effect transistors. J. Mater. Chem. C 2019, 7, 10257-10263. [CrossRef]

175. Li, R.; Wang, L.; Yin, L. Materials and Devices for Biodegradable and Soft Biomedical Electronics. Materials 2018, 11, 2108. [CrossRef] [PubMed]

176. Ahmad, N.A.; Goh, P.S.; Abdul Karim, Z.; Ismail, A.F. Thin Film Composite Membrane for OilyWaste Water Treatment: Recent Advances and Challenges. Membranes 2018, 8, 86. [CrossRef] [PubMed]

177. Khulbe, K.C.; Matsuura, T. Thin Film Composite and/or Thin Film Nanocomposite Hollow Fiber Membrane for Water Treatment, Pervaporation, and Gas/Vapor Separation. Polymers 2018, 10, 1050. [CrossRef]

178. Pang, Y.; Xi, F.; Luo, J.; Liu, G.; Guo, T.; Zhang, C. An alginate film-based degradable triboelectric nanogenerator. RSC Adv. 2018, 8, 6719-6726. [CrossRef]

179. Zhang, M.; Gao, Y.; Zhan, Y.; Ding, X.; Wang, M.; Wang, X. Preparing the Degradable, Flame-Retardant and Low Dielectric Constant Nanocomposites for Flexible and Miniaturized Electronics with Poly(lactic acid), Nano ZIF-8@GO and Resorcinol Di(phenyl phosphate). Materials 2018, 11, 1756. [CrossRef]

180. Liu, R.; Zhu, L.Q.; Wang, W.; Hui, X.; Liu, Z.P.; Wan, Q. Biodegradable oxide synaptic transistors gated by a biopolymer electrolyte. J. Mater. Chem. C 2016, 4, 7744-7750. [CrossRef]

181. Aldana, A.A.; Toselli, R.; Strumia, M.C.; Martinelli, M. Chitosan films modified selectively on oneside with dendritic molecules. J. Mater. Chem. 2012, 22, 22670-22677. [CrossRef] 
182. Liang, D.-K.; Chen, Y.-H.; Xu, W.; Ji, X.-C.; Tong, Y.; Wu, G.-D. Ultralow-voltage albumen-gated electric-double-layer thin film transistors. Acta Phys. Sin. 2018, 67, 237302. [CrossRef]

183. Liu, C.; Li, W.; Li, H.; Zhang, C.; Fan, J.; Mai, Y. C60 additive-assisted crystallization in $\mathrm{CH}_{3} \mathrm{NH}_{3} \mathrm{~Pb}_{0.75} \mathrm{Sn}_{0.25} \mathrm{I}_{3}$ perovskite solar cells with high stability and efficiency. Nanoscale 2017, 9, 13967-13975. [CrossRef] [PubMed]

184. Azarian, M.H.; Boochathum, P.; Kongsema, M. Biocompatibility and biodegradability of filler encapsulated chloroacetated natural rubber/polyvinyl alcohol nanofiber for wound dressing. Mater. Sci. Eng. C 2019, 103, 1-9. [CrossRef] [PubMed]

185. Mohamed, M.A.; Salleh, W.N.; Jaafar, J.; Ismail, A.F.; Abd Mutalib, M.; Jamil, S.M. Incorporation of N-doped $\mathrm{TiO}_{2}$ nanorods in regenerated cellulose thin films fabricated from recycled newspaper as a green portable photocatalyst. Carbohydr. Polym. 2015, 133, 429-437. [CrossRef] [PubMed]

186. Ay, S.B.; Perkgoz, N.K. Nanotechnological Advances in Catalytic Thin Films for Green Large-Area Surfaces. J. Nanomater. 2015, 2015, 1-20. [CrossRef]

187. Zheng, Q.; Zou, Y.; Zhang, Y.; Liu, Z.; Shi, B.; Wang, X.; Jin, Y.; Ouyang, H.; Li, Z.; Wang, Z.L. Biodegradable triboelectric nanogenerator as a life-time designed implantable power source. Sci. Adv. 2016, 2, 2375-2548. [CrossRef]

188. Shi, X.; Liao, Y.-M.; Lin, H.-Y.; Tsao, P.-W.; Wu, M.-J.; Lin, S.-Y.; Hu, H.-H.; Wang, Z.; Lin, T.-Y.; Lai, Y.-C. Dissolvable and Recyclable Random Lasers. ACS Nano 2017, 11, 7600-7607. [CrossRef]

189. Xu, F.; Zhang, H.; Jin, L.; Li, Y.; Li, J.; Gan, G.; Wei, M.; Li, M.; Liao, Y. Controllably degradable transient electronic antennas based on water-soluble $\mathrm{PVA} / \mathrm{TiO}_{2}$ films. J. Mater. Sci. 2017, 53, 2638-2647. [CrossRef]

190. Park, M.-J.; Lee, J.-S. Foldable and Biodegradable Energy-Storage Devices on Copy Papers. Adv. Electron. Mater. 2019, 5, 1-6. [CrossRef]

191. Irimia-Vladu, M.; Troshin, P.A.; Reisinger, M.; Shmygleva, L.; Kanbur, Y.; Schwabegger, G.; Bodea, M.; Schwödiauer, R.; Mumyatov, A.; Fergus, J.W.; et al. Biocompatible and Biodegradable Materials for Organic Field-Effect Transistors. Adv. Funct. Mater. 2010, 20, 4069-4076. [CrossRef]

192. Hwang, S.-W.; Kim, D.-H.; Tao, H.; Kim, T.-i.; Kim, S.; Yu, K.J.; Panilaitis, B.; Jeong, J.-W.; Song, J.-K.; Omenetto, F.G.; et al. Materials and Fabrication Processes for Transient and Bioresorbable High-Performance Electronics. Adv. Funct. Mater. 2013, 23, 4087-4093. [CrossRef]

193. Guo, J.; Liu, J.; Yang, B.; Zhan, G.; Kang, X.; Tian, H.; Tang, L.; Chen, X.; Yang, C. Low-voltage transient/biodegradable transistors based on free-standing sodium alginate membranes. IEEE Electron Device Lett. 2015, 36, 576-578. [CrossRef]

194. Chua, L. Memristor: The missing circuit element. IEEE Trans. Circuit Theory 1971, 18, 507-519. [CrossRef]

195. Hickmott, T.W. Low-Frequency Negative Resistance in Thin Anodic Oxide Films. J. Appl. Phys. 1962, 33, 2669-2682. [CrossRef]

196. Gibbons, J.F.; Beadle, W.E. Switching properties of thin NiO films. Solid State Electron. 1964, 7, 785-790. [CrossRef]

197. Kwon, D.-H.; Kim, K.M.; Jang, J.H.; Jeon, J.M.; Lee, M.H.; Kim, G.H.; Li, X.-S.; Park, G.-S.; Lee, B.; Han, S.; et al. Atomic structure of conducting nanofilaments in $\mathrm{TiO}_{2}$ resistive switching memory. Nat. Nanotechnol. 2010, 5, 148-153. [CrossRef]

198. Chang, W.-Y.; Lai, Y.-C.; Wu, T.-B.; Wang, S.-F.; Chen, F.; Tsai, M.-J. Unipolar resistive switching characteristics of $\mathrm{ZnO}$ thin films for nonvolatile memory applications. Appl. Phys. Lett. 2008, 92, 022110. [CrossRef]

199. Jeong, K.W.; Do, Y.H.; Yoon, K.S.; Kim, C.O.; Hong, J.P. Resistive switching characteristics of unique binary-oxide $\mathrm{MgO}_{\mathrm{x}}$ films. J. Korean Phys. Soc. 2006, 48, 1501-1504.

200. Kim, S.; Biju, K.P.; Jo, M.; Jung, S.; Hwang, H. Effect of Scaling $\mathrm{WO}_{\mathrm{x}}$-Based RRAMs on Their Resistive Switching Characteristics. IEEE Electron Device Lett. 2011, 32, 671-673. [CrossRef]

201. Asamitsu, A.; Tomioka, Y.; Kuwahara, H.; Tokura, Y. Current switching of resistive states in magnetoresistive manganites. Nature 1997, 388, 50-52. [CrossRef]

202. Strukov, D.B.; Snider, G.S.; Stewart, D.R.; Williams, R.S. The missing memristor found. Nature 2008, 453, 80-83. [CrossRef] [PubMed]

203. Zhong, S.; Ji, X.; Song, L.; Zhang, Y.; Zhao, R. Enabling Transient Electronics with Degradation on Demand via Light-Responsive Encapsulation of a Hydrogel-Oxide Bilayer. ACS Appl. Mater. Interfaces 2018, 10, 36171-36176. [CrossRef] [PubMed]

204. Zhang, Z.; Tsang, M.; Chen, I.W. Biodegradable resistive switching memory based on magnesium difluoride. Nanoscale 2016, 8, 15048-15055. [CrossRef] 
205. Hosseini, N.R.; Lee, J.-S. Biocompatible and Flexible Chitosan-Based Resistive Switching Memory with Magnesium Electrodes. Adv. Funct. Mater. 2015, 25, 5586-5592. [CrossRef]

206. Wu, W.; Han, S.-T.; Venkatesh, S.; Sun, Q.; Peng, H.; Zhou, Y.; Yeung, C.; Li, R.K.Y.; Roy, V.A.L. Biodegradable skin-inspired nonvolatile resistive switching memory based on gold nanoparticles embedded alkali lignin. Org. Electron. 2018, 59, 382-388. [CrossRef]

207. Song, F.; Wang, H.; Sun, J.; Gao, H.; Wu, S.; Yang, M.; Ma, X.; Hao, Y. ZnO-Based Physically Transient and Bioresorbable Memory on Silk Protein. IEEE Electron Device Lett. 2018, 39, 31-34. [CrossRef]

208. Liu, D.; Jing, Q.; Cheng, H. Synaptic-functional and fully water-soluble transient memristor made from materials compatible with semiconductor technology. Jpn. J. Appl. Phys. 2019, 58, 060903. [CrossRef]

209. Zhong, S.; Ji, X.; Zhou, Y.; Zhang, Y.; Ye, A.; Zhao, R. CMOS Compatible Transient Resistive Memory with Prolonged Lifetime. Adv. Mater. Technol. 2019, 4, 1900217. [CrossRef]

210. Sun, J.; Wang, H.; Wang, Z.; Song, F.; Zhu, Q.; Dang, B.; Gao, H.; Yang, M.; Ma, X.; Hao, Y. Physically Transient Memristive Synapse With Short-Term Plasticity Based on Magnesium Oxide. IEEE Electron Device Lett. 2019, 40, 706-709. [CrossRef]

211. Ji, X.; Song, L.; Zhong, S.; Jiang, Y.; Lim, K.G.; Wang, C.; Zhao, R. Biodegradable and Flexible Resistive Memory for Transient Electronics. J. Phys. Chem. C 2018, 122, 16909-16915. [CrossRef]

212. Yan, X.; Li, X.; Zhou, Z.; Zhao, J.; Wang, H.; Wang, J.; Zhang, L.; Ren, D.; Zhang, X.; Chen, J.; et al. Flexible Transparent Organic Artificial Synapse Based on the Tungsten/Egg Albumen/Indium Tin Oxide/Polyethylene Terephthalate Memristor. ACS Appl. Mater. Interfaces 2019, 11, 18654-18661. [CrossRef] [PubMed]

213. Wang, H.; Zhu, B.; Ma, X.; Hao, Y.; Chen, X. Physically Transient Resistive Switching Memory Based on Silk Protein. Small 2016, 12, 2715-2719. [CrossRef] [PubMed]

(C) 2020 by the authors. Licensee MDPI, Basel, Switzerland. This article is an open access article distributed under the terms and conditions of the Creative Commons Attribution (CC BY) license (http://creativecommons.org/licenses/by/4.0/). 